\title{
BMJ Open What long-term care interventions have been published between 2010 and 2020? Results of a WHO scoping review identifying long-term care interventions for older people around the world
}

To cite: Arias-Casais N, Amuthavalli Thiyagarajan J, Rodrigues Perracini M, et al. What long-term care interventions have been published between 2010 and 2020? Results of a WHO scoping review identifying long-term care interventions for older people around the world. BMJ Open 2022;12:e054492. doi:10.1136/ bmjopen-2021-054492

- Prepublication history and additional supplemental material for this paper are available online. To view these files, please visit the journal online (http://dx.doi.org/10.1136/ bmjopen-2021-054492)

Received 08 July 2021 Accepted 20 December 2021

Check for updates

(C) Author(s) (or their employer(s)) 2022. Re-use permitted under CC BY-NC. No commercial re-use. See rights and permissions. Published by BMJ.

For numbered affiliations see end of article.

Correspondence to

Dr Zee-A Han;

hanzeea@gmail.com

\section{ABSTRACT}

Objective The global population is rapidly ageing. To tackle the increasing prevalence of older adults' chronic conditions, loss of intrinsic capacity and functional ability, long-term care interventions are required. The study aim was to identify long-term care interventions reported in scientific literature from 2010 to 2020 and categorise them in relation to WHO's public health framework of healthy ageing.

Design Scoping review conducted on PubMed, CINHAL, Cochrane and Google Advanced targeting studies reporting on long-term care interventions for older and frail adults. An internal validated Excel matrix was used for charting.

Setting nursing homes, assisted care homes, long-term care facilities, home, residential houses for the elderly and at the community.

Inclusion criteria Studies published in peer-reviewed journals between 1 January 2010 to 1 February 2020 on implemented interventions with outcome measures provided in the settings mentioned above for subjects older than 60 years old in English, Spanish, German, Portuguese or French.

Results 305 studies were included. Fifty clustered interventions were identified and organised into four WHO Healthy Ageing domains and 20 subdomains. All interventions delved from high-income settings; no interventions from low-resource settings were identified. The most frequently reported interventions were multimodal exercise $(n=68$ reports, person-centred assessment and care plan development $(n=22)$, case management for continuum care $(n=16)$, multicomponent interventions ( $n=15)$, psychoeducational interventions for caregivers $(n=13)$ and interventions mitigating cognitive decline $(n=13)$.

Conclusion The identified interventions are diverse overarching multiple settings and areas seeking to prevent, treat and improve loss of functional ability and intrinsic capacity. Interventions from low-resource settings were not identified.

\section{Strengths and limitations of this study}

This study used a scoping review methodology to identify long-term care interventions in the scientific literature in the last 10 years.

- This study categorised the retrieved interventions into the domains of WHO articulated definition of Healthy Ageing.

- This study focused its search on internationaloverarching databases and did not conduct search on regional databases were local interventions might be published.

- This study did not focus on the effectiveness of the individual interventions.

\section{BACKGROUND}

At a time of multiple and changing public health challenges, one issue remains certain: the world population is ageing rapidly. ${ }^{1}$ From 2015 to 2050, the proportion of the world's population aged 60 years or older will more than double. ${ }^{1}$ Longer lives and an older population age structure, without a reduction in the incidence of disease burden, is expected to result in a higher prevalence of non-communicable diseases at the population level, and increasing comorbidity at the individual level. These trends will increase the demand for effective services and require prompt responses from health systems and more enabling environments. Increasing burden of chronic conditions will result in a decline in intrinsic capacity and functioning of the global population, creating enormous challenges in all aspects of society and most importantly health and social care. ${ }^{1}$

In 2015, WHO articulated a definition for Healthy Ageing as 'the process of developing and maintaining the functional ability that 
enables well-being in older age. ${ }^{2}$ Through functional ability, WHO has prioritised achieving meaningful living despite moderate to significant declines in physical or mental capacity. ${ }^{2}$ The provision of long-term care services aims at: 'ensuring that people with or at risk of significant loss of physical and mental capacity can maintain a level of functional ability consistent with their basic rights, fundamental freedoms and human dignity'. ${ }^{2}$ These services, typically non-hospital based, are provided in various settings, involve care and assistance with everyday tasks, support with social participation, and management of advanced chronic conditions through community nursing, rehabilitation and palliative and end-of-life care. $^{23}$

As the number of older persons continues to grow so will the need for long-term care. In countries from the Organisation for Economic Cooperation and Development, older adults above 80 years are driving the increased demand and supply of long-term care. An estimate average of $52 \%$ of people above 80 years require some kind of long-term care support but remain without access. ${ }^{4}$ The unmet need for long-term care is particularly pronounced in low-middle income countries (LMICs), ${ }^{1}{ }^{4}$ many of which are experiencing an epidemiological transition and where the majority of older people live. It is projected that more than $80 \%$ of older people will be living in LMICs in 2050. ${ }^{124}$ As a result, an increase in prevalence of need for long-term care is expected. ${ }^{5}$ The WHO strives to close this gap. To do so, the appraisal of long-term care provision globally is deemed a necessary first step.

While there has been a boom in publications reporting on long-term care provision in the last 10 years, ${ }^{6}$ scarce systematic assessment has been conducted exploring long-term care interventions and services. Only few studies have targeted this matter focusing on specific thematic areas such as oral health, ${ }^{7}$ caregivers, ${ }^{8}$ comprehensive geriatric assessment, ${ }^{9}$ delirium and dementia, ${ }^{10-14}$ telemedicine and videogames, ${ }^{15}$ health promotion, ${ }^{16} 17$ fall prevention and injury reduction, ${ }^{18}{ }^{19}$ multicomponent interventions, ${ }^{20}{ }^{21}$ nutrition, ${ }^{22}$ occupational therapy, ${ }^{23}$ physical activity, ${ }^{24-32}$ and models of care. ${ }^{33} 34$

The provision and access to long term care for older people who need it, is one of the four key action areas endorsed by all WHO and UN Member States, within the UN Decade of Healthy Ageing, endorsed in 2020. The importance to identify and evaluate interventions that mitigate declines in capacities and maintain dignity and older person's ability sets the stage for this study.

Following a scoping review methodology, this study answered the question: What long-term care interventions have been published between 2010 and 2020? and aimed to systematically assess the scientific literature reporting on long-term care interventions and services for older adults available globally within the mentioned period of time. Its main objective is to provide an overview of the currently reported interventions and to propose a categorisation for its better appraisal. This study has been conducted in preparation of a WHO process to enable a long-term care package of services.

\section{METHODS}

A scoping review is considered to be the most appropriate method to address the aim of this study as this method has been traditionally used to scan large and unexplored bodies of evidence with the aim of better understanding its content and gaps. ${ }^{35} 36$ To the best of our knowledge, this study is one of the first efforts to systematically exploring long-term care interventions provided around the world. A research protocol was drafted and internally approved by the research team. The scoping review was conducted between February and June 2020 following the Preferred Reporting Items for Systematic Reviews and Meta-Analyses extension for Scoping Reviews (PRISMA-ScR) reporting guidance $^{35} 37$ and is reported following the PRISMA-ScR checklist and diagram (figure 1). ${ }^{35} 38$

\section{Inclusion criteria}

The following inclusion criteria were established: (1) Studies published in peer-reviewed journals, (2) published between 1 January 2010 to 1 February 2020; we have chosen this time frame based on the scientometric review by $\mathrm{Fu}$ et a ${ }^{69}$ in which a burst of publications from 2010 onwards was reported (3) Provided in one of the following settings: nursing homes, assisted care homes, long-term care facilities, home, residential houses for the elderly and at the community; (4) reporting on subjects older than 60 years old; (5) providing a detailed description of the interventions' components (including a description on materials, personnel and its implementation); (6) the reported intervention had to be already implemented either in research or real life context (ie, only studies reporting on the results of an implemented intervention were included, protocols or plans were excluded); (7) studies had to report on at least one outcome measure assessing the implementation of the intervention; (8) reporting on non-pharmacological (ie, we included interventions relying on behavioural modifications and support of intrinsic capacity without requiring medical prescriptions: ie, pharmacological intervention like anticoagulants were excluded) interventions except those related to preventative public health measures such as vaccination and (9) addressing older adults at risk of or living with frailty and intrinsic capacity loss.

\section{Exclusion criteria}

Studies were excluded if: (1) they were published out of the defined dates; (2) did not provide a description of the component(s) of the interventions; (3) were delivered at the hospital setting in the context of acute care (ie, emergency room) or hospitalisation; (4) occurred in the context of transitional care (ie, from the orthopaedic ward to home after hip surgery); (5) reported on acute, subacute or postacute episode; (6) long-term care for any other population (ie, children); (7) dissertations, 

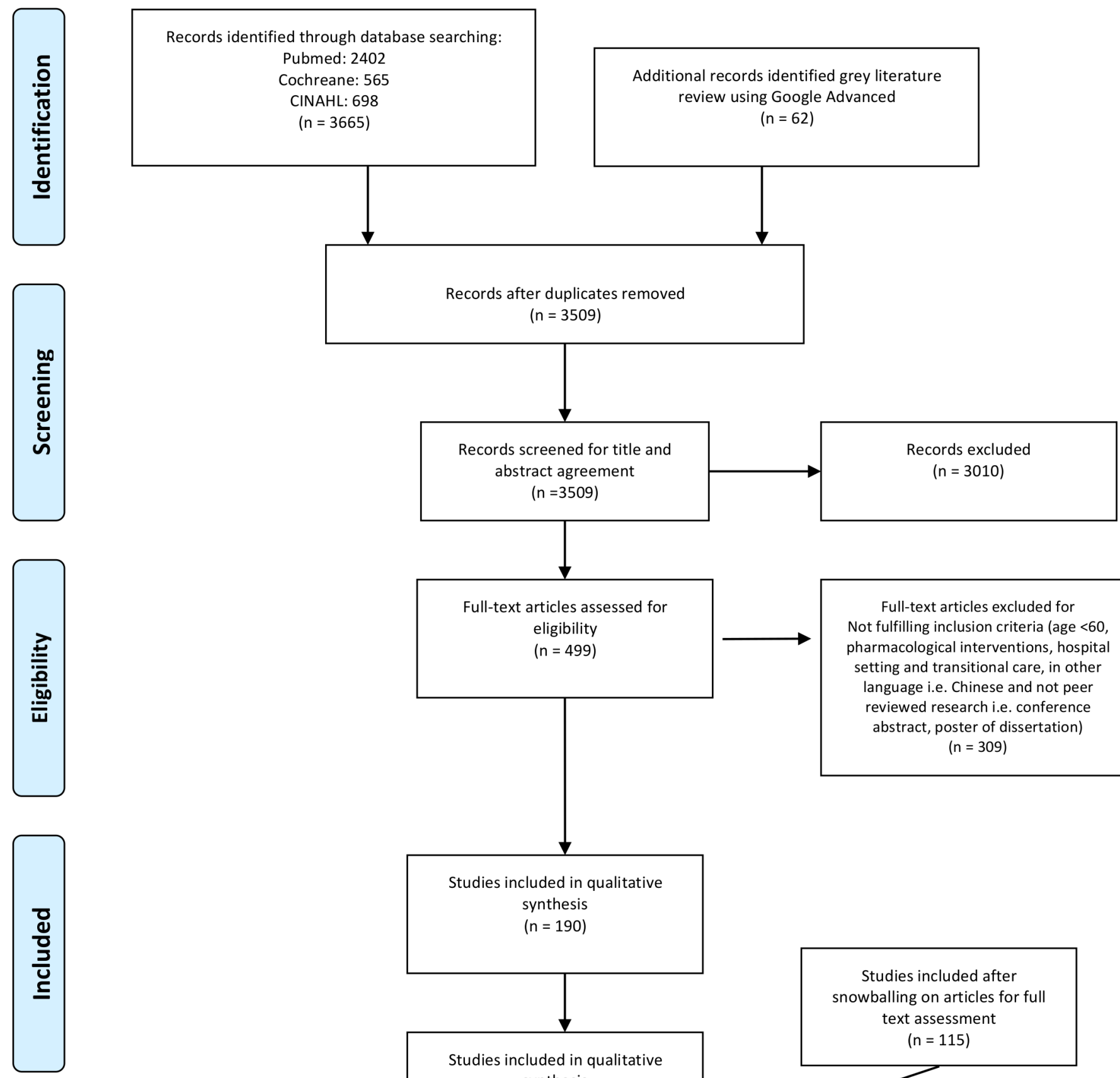

Figure 1 Shows the process followed to select the articles included in this study. Repeated articles were deleted. Two researches (NA-C and BW) independently reviewed all articles by title and abstract. On title and abstract agreement, articles were selected for full text assessment. Discrepancies were discussed to reach agreement (NA-C, BW and Z-AH). Articles selected for full-text assessment were downloaded and managed using the MENDELEY reference manager software. An additional 'snow-balling'43 approach was conducted on the reference section of selected articles to identify other relevant studies. Adapted from Moher et al..$^{38}$

doctoral thesis, conference communications, posters, abstracts, protocols, courses and training material; (8) studies reporting only outcome measures for economic evaluation; (9) pharmacological interventions; (10) Longterm effects of medications, surgeries or other acute or hospital-based interventions and (11) we excluded articles reported in languages other than English, Spanish, German, Portuguese and French. These languages were targeted based on the research team proficiency and with the aim of broadening the search over English articles. 


\begin{tabular}{|c|c|c|}
\hline & Concept & MeSH \\
\hline Population & $\begin{array}{l}\text { Older adult } \\
\text { Frail elderly } \\
\text { Older people } \\
\text { Elderly }\end{array}$ & $\begin{array}{l}\text { "Aged"[Mesh] } \\
\text { "Frail elderly"[Mesh] }\end{array}$ \\
\hline Context & $\begin{array}{l}\text { Long-term care } \\
\text { facilities } \\
\text { Nursing homes } \\
\text { Home and } \\
\text { community based } \\
\text { services } \\
\text { Community health } \\
\text { services } \\
\text { Caregivers } \\
\text { Social services }\end{array}$ & $\begin{aligned} & \text { "Long-term care"[Mesh] } \\
& \text { "Nursing homes"[Mesh] } \\
& \text { "Homes for the aged } \\
& \text { [Mesh] } \\
& \text { - Long term care facilities } \\
& \text { "Assisted living } \\
& \text { facilities" [Mesh] } \\
& \text { "Community health } \\
& \text { services [Mesh] } \\
& \text { Home care } \\
& \text { "Caregivers"[Mesh] } \\
& \text { "Social services" [Mesh] } \\
& \text { Social care }\end{aligned}$ \\
\hline Concept & $\begin{array}{l}\text { Long-term care } \\
\text { services OR } \\
\text { interventions } \\
\text { Provision } \\
\text { Package of } \\
\text { services }\end{array}$ & $\begin{array}{l}\text { Long-term care } \\
\text { Health services for the } \\
\text { aged [Mesh] } \\
\text { Intervention [Mesh] } \\
\text { Services }\end{array}$ \\
\hline
\end{tabular}

\section{Search engines and strategy}

Peer-review studies were searched in PubMed, CINAHL (EBSCO Host) and in Cochrane database. An additional search was conducted in Google Advanced to assess grey literature, allowing the identification of evidence-based reports that are normally excluded from indexed journals. No regional databases were searched. A combination of the following terms (table 1) was used and specifically adapted to the characteristics of each search engine under the supervision of the Library Service at the University of Navarra (online supplemental boxes 2-5): Long-term care OR/AND, health services for the aged, AND/OR social services, AND/OR, social care, AND, interventions, OR services, AND long-term care facilities, OR assisted living facilities, OR nursing homes, OR homes for the aged, OR home care, OR community health services, OR Caregivers, AND older adult, AND frail elderly.

\section{Article selection and article categorisation}

\section{Data charting}

The interventions were extracted from the articles included in the study (NA-C and RS). From each intervention data were gathered using an internally validated charting form drafted in Excel MS Office 2019 that targeted: type of study, demographic characteristics of the study population, country, intervention description, delivery setting, provider, delivery frequency, duration, outcome measures and conclusions. Specific information regarding these fields is not provided.
Repeated interventions were deleted. That is, in the case a same intervention was reported twice in two different studies (ie, a research group reported an intervention first in an randomised control trial and later in a cost-effectiveness secondary analysis) the intervention was counted only once. In this case, the study presenting more data to complete the charting form was used as reference. This general method was used for studies included in systematic reviews. Following the inclusion criteria, studies prior to 2010 were excluded even if they were being reported in a systematic review from 2010 and onward.

\section{Data analysis}

The identified interventions were approached using nonsoftware based cluster analysis (NA-C, RS and Z-AH). The aim of this qualitative approach was finding similarities between the interventions and grouping them accordingly. First, interventions were organised into thematic areas following WHO's Healthy Ageing domains, namely: intrinsic capacity, functional ability, and environment (specifically support provided by caregivers). (2) The interventions within each thematic area were clustered according to similarity and coded. On them, cluster analysis was conducted to identify a common underlying concepts and associations. Associated interventions were included in a cluster. The interventions contained in a same cluster received a heading. This name aimed at synthetising the cluster content. Naming was aligned with WHO's official wording used in guidelines and official reports (MRP). Two researches conducted independently the clusterisation (NA-C and MRP), decisions and disagreements where discussed. A third researcher (Z-AH) reviewed the decisions.

Frequency of appearance was calculated as the number of interventions contained within one cluster. The frequency of appearance was placed next to the cluster denomination, indicating how often the intervention was reported.

The scope of this study aimed at scanning the scientific literature to gain an overview of the long-term care interventions provided around the world and approach its appraisal in a descriptive manner. Given the exploratory scope and the scoping review nature of this study, no assessment of the quality of included studies or identified interventions was conducted.

\section{RESULTS}

\section{Identified studies and characteristics}

A total of 3727 articles were identified; after duplicates were removed, 3509 were assessed for title and abstract agreement. A total of 499 articles were selected for fulltext assessment, from which only 190 were included in qualitative synthesis. Additional 150 articles were identified through snowballing and included in qualitative synthesis, leaving a total of 305 articles assessed (figure 1). 
Table 2 Typology of the identified studies

\begin{tabular}{lcc}
\hline Study design & $\begin{array}{l}\text { No of } \\
\text { studies } \\
\text { identified }\end{array}$ & $\begin{array}{l}\% \text { of } \\
\text { identified } \\
\text { studies }\end{array}$ \\
\hline Randomised control trial & 181 & 59.3 \\
\hline Systematic review & 28 & 9.2 \\
\hline Quasi-experimental & 25 & 8.2 \\
\hline Pre/post & 14 & 4.6 \\
\hline Descriptive & 10 & 3.3 \\
\hline Cohort & 8 & 2.6 \\
\hline Cross sectional & 7 & 2.3 \\
\hline Observational & 6 & 2.0 \\
\hline Case and control & 3 & 1.0 \\
\hline Case reports & 2 & 0.7 \\
\hline Controlled trial & 2 & 0.7 \\
\hline Experimental & 2 & 0.7 \\
\hline Experimental cross over & 2 & 0.7 \\
\hline Mix methods & 2 & 0.7 \\
\hline Non-randomised trials & 2 & 0.7 \\
\hline Randomised intervention study & 2 & 0.7 \\
\hline Scoping review & 2 & 0.7 \\
\hline Cost-effectiveness & 1 & 0.3 \\
\hline Designed-delay & 1 & 0.3 \\
\hline Integrative review & 1 & 0.3 \\
\hline Matched control group & 1 & 0.3 \\
\hline Prospective intervention study & 1 & 0.3 \\
\hline Not specified & 2 & 0.7 \\
\hline Total & 305 & 100.0 \\
\hline & & \\
\hline
\end{tabular}

The majority of the identified studies were randomised controlled trials $(\mathrm{n}=181,59.3 \%)$, followed by systematic reviews $(\mathrm{n}=28,9.2 \%)$, and quasi-experimental studies $(\mathrm{n}=25,8.2 \%)$ (table 2). The top three publishing journals were the Journal of American Medical Directors Association $(n=17)$, Journal of American Geriatric Society $(n=13)$ and BMC Geriatrics $(\mathrm{n}=11)$ (table 3). A total of 38 studies were identified in 2010, followed by 34 in 2011 and 36 in 2012. A trend to decrease the number of publications followed the year 2014.

An under-representation of interventions from LMIC was identified (please see online supplemental table $8)$. All of the included studies corresponded to interventions identified in high-income (HIC) or uppermiddle-income countries (UMC) according to the latest classification of the World Bank. ${ }^{40}$ The majority of the studies were conducted and published within the United States of America $(\mathrm{n}=56 ; 18 \%)$, followed by China, Taiwan $(\mathrm{n}=39 ; 13 \%)$, The Netherlands $(\mathrm{n}=19 ; 6 \%)$, Japan $(\mathrm{n}=18 ; 6 \%)$, Australia $(\mathrm{n}=15 ; 5 \%)$, Sweden $(\mathrm{n}=14,5 \%)$, United Kingdom $(\mathrm{n}=14,5 \%)$, Canada $(\mathrm{n}=11 ; 4 \%)$ and Spain $(n=10,3 \%)$. Articles from UMCs reporting interventions were: Brazil $(n=4 ; 1 \%)$, Argentina $(n=2 ; 0.7 \%)$,
Table 3 Top 10 journals publishing on LTC interventions

\begin{tabular}{ll}
\hline Journal & $\begin{array}{l}\text { No of } \\
\text { articles } \\
\text { identified }\end{array}$ \\
\hline $\begin{array}{l}\text { Journal of American Medical Directors } \\
\text { Association }\end{array}$ & 17 \\
\hline Journal of American Geriatric Society & 13 \\
\hline BMC Geriatrics & 11 \\
\hline Clinical Interventions in Aging & 9 \\
\hline Archives of Gerontology and Geriatrics & 7 \\
\hline International Journal of Nursing Studies & 7 \\
\hline International Psychogeriatric & 7 \\
\hline Ageing Clinical and Experimental Research & 6 \\
\hline Geriatrics \& Gerontology International & 6 \\
\hline Journal of Clinical Nursing & 6 \\
\hline
\end{tabular}

Colombia $(\mathrm{n}=1 ; 0.3 \%)$, Mexico $(\mathrm{n}=1 ; 0.3 \%)$, and Turkey $(\mathrm{n}=1 ; 0.3 \%)$. No interventions based in low-income or low-middle-income countries were identified in this study.

\section{Identified interventions}

Table 4 shows a summary of the findings. A total of 273 interventions using different formulations were identified. By 'different formulations' we refer to the different nomenclatures used in the source study. For example, one intervention could be named as 'Stretching exercise' in study A, while study B would call it 'exercise to improve stretching' and study C 'silver yoga to improve stretching'. During the cluster analysis, these interventions were grouped under stretching exercises.

Analysis delved a total of 49 clusters, which were organised in four domains: (1) Interventions to support caregivers and enable care-planning based on person-centred assessment, (2) Interventions for the maintenance of intrinsic capacity, (3) Interventions for the optimisation of functional ability and (4) Additional environmental and structural interventions. Tables $4-7$ provide an overview of the identified interventions organised per domains and subdomains.

In terms of delivery setting, long-term care facilities predominated $(n=85)$, followed by home $(n=73)$, and community $(n=46)$. No specific definitions regarding the settings were provided within the studies.

The most frequently reported interventions were: multimodal exercise programme ( $\mathrm{n}=68$ reports), personcentred assessment and care plan development $(n=22)$, case management, coordination and timely referral to ensure patient-centred continuum care $(n=16)$, multicomponent interventions $(n=15)$, interventions aimed at mitigating/preventing cognitive decline $(n=13)$, psychoeducational interventions for caregivers $(n=13)$, screen and management of polypharmacy $(n=7)$, use of telemedicine to provide long-term care services $(n=7)$ and interventions to foster continued opportunities for learning, growing and decision making $(\mathrm{n}=6)$, 
Table 4 Summary table

\begin{tabular}{|c|c|c|c|}
\hline WHO healthy ageing domain & Subdomain & $\begin{array}{l}\text { Total no of } \\
\text { clusters }\end{array}$ & $\begin{array}{l}\text { Total frequency } \\
\text { of appearance }\end{array}$ \\
\hline $\begin{array}{l}\text { Interventions to support caregivers and enable } \\
\text { care-planning based on person-centred } \\
\text { assessment }\end{array}$ & Caregiver support & 13 & 34 \\
\hline \multirow{6}{*}{$\begin{array}{l}\text { Interventions for the maintenance of intrinsic } \\
\text { capacity }\end{array}$} & Vitality (nutrition and hydration) & 4 & 15 \\
\hline & Oral health & 1 & 7 \\
\hline & Cognitive capacity & 3 & 19 \\
\hline & Psychological capacity & 2 & 7 \\
\hline & Sleep hygiene & 1 & 4 \\
\hline & Locomotor capacity & 2 & 71 \\
\hline \multirow{2}{*}{$\begin{array}{l}\text { Interventions for the optimisation of functional } \\
\text { ability }\end{array}$} & Build and maintain relationships & 2 & 5 \\
\hline & Learn, grow and make decisions & 1 & 6 \\
\hline \multirow{7}{*}{$\begin{array}{l}\text { Additional environmental and structural } \\
\text { interventions }\end{array}$} & Modification to the built environment & 2 & 6 \\
\hline & Fall prevention & 3 & 11 \\
\hline & Pain management & 1 & 1 \\
\hline & Polypharmacy & 1 & 7 \\
\hline & Palliative care and end of life care & 1 & 1 \\
\hline & Digital Health & 2 & 8 \\
\hline & Management of communicable disease & 1 & 2 \\
\hline
\end{tabular}

Interventions to support caregivers and enable care-planning based on person-centred assessment

Within the subdomain for caregiver support (table 5), the most frequently appearing interventions were psychoeducational interventions to foster self-care, psychological hygiene, stress management and coping strategies for informal caregivers. The majority of the interventions corresponded to the provision of support for caregivers of people with dementia (PWD) or Alzheimer. Additionally, the need for training was made evident; several studies addressed this issue by reporting on different training interventions mainly targeting paid caregivers.

Interestingly, a total of 22 studies reported interventions stressing person-centred assessment for care planning. A comprehensive geriatric assessment to identify older people's needs was majorly conducted to design adjusted care plans and inform decision-making regarding care management, delivery and referral. This elevated frequency of appearance made it the second most reported intervention within this study. Also particularly relevant were the interventions addressing care management. These interventions proposed a figure specially designed to manage and coordinate care for older adults, mostly in the form of a trained nurse. The common objective was the timely referral to social and clinical services and pursue of a continuum of care.

\section{Interventions for the maintenance of intrinsic capacity}

This domain accounts for the greatest number of studies included (table 6). The interventions addressed several areas for the maintenance of intrinsic capacity. Those to prevent malnutrition and dehydration focused on scheduled mealtimes and increase of caloric intake by providing between meals snacks and beverages. Approaches based on food modification were also reported, especially to prevent dysphagia and to facilitate intake by providing finger food.

The promotion of oral care and the timely identification of related problems were frequently reported in the literature. Most of these interventions stressed screening programmes. The prevention of pressure ulcers was mainly addressed through interventions addressing skin care routines and the use of cushions.

The prevention of cognitive decline seems to be a common interest in the provision of long-term care especially for PWD. Studies reported interventions promoting the social integration of older people by means of occupational therapy, reminiscence exercises, well-being 
Table 5 Interventions to support caregivers and enable care-planning based on person-centred assessment $(n=16)$

\begin{tabular}{|c|c|c|c|c|}
\hline Subdomain & $\begin{array}{l}\text { Clustered } \\
\text { interventions }\end{array}$ & $\begin{array}{l}\text { Frequency of } \\
\text { appearance }\end{array}$ & Reference & Examples of included interventions* \\
\hline \multirow[t]{11}{*}{$\begin{array}{l}\text { Caregiver } \\
\text { support } \\
(n=13)\end{array}$} & $\begin{array}{l}\text { Psychoeducational } \\
\text { interventions }\end{array}$ & 13 & $\begin{array}{l}\text { Jalali and Wohlin, }{ }^{43} \text { Cheng } \\
\text { et al, }{ }^{44} \text { Chu et } a l,{ }^{45} \text { Wang et } \\
\text { al }{ }^{46} \mathrm{Au} \text { et } a l,{ }^{47} \text { Kwok et al, } \\
\text { Chen et } a l^{49} \mathrm{Au},{ }^{50} \text { Kwok et } \\
a{ }^{51}{ }^{5} \text { Velásquez et al, }{ }^{52} \mathrm{Au},{ }^{53} \\
\text { Cooper et al, }{ }^{54} \text { Logsdon et al } \\
2010^{55}\end{array}$ & $\begin{array}{l}\text { Psychoeducation for PWD caregivers, }{ }^{43} \\
4448 \text { Support group for PWD caregivers, }{ }^{45} \\
{ }^{46} \text { Support group for PWA caregivers, }{ }^{47} \\
\text { Coping strategies for PWD caregivers, } \\
\text { Behavioural activation for PWD } \\
\text { caregivers, }{ }^{50} \text { Behavioural therapy for PWD } \\
\text { family caregivers, }{ }^{51} \text { Psychoeducation for } \\
\text { older adults caregivers, }{ }^{52} \text { Self-care for } \\
\text { PWD caregivers, }{ }^{53} \text { Abuse prevention for } \\
\text { PWD family caregivers, }{ }^{54} \text { Psychoeducation } \\
\text { on memory loss for caregivers and older } \\
\text { adults. }{ }^{55}\end{array}$ \\
\hline & $\begin{array}{l}\text { Training on specific } \\
\text { geriatric syndromes, } \\
\text { health conditions and } \\
\text { skills-based care }\end{array}$ & 3 & $\begin{array}{l}\text { Huang et al, }{ }^{56} \text { Simmons et } \\
a{ }^{57}{ }^{5} \text { Ford et al }{ }^{58}\end{array}$ & $\begin{array}{l}\text { Trainning on aggresive bahaviour of people } \\
\text { with dementia, }{ }^{56} \text { Nutritional care delivery } \\
\text { for nonnursing staff, }{ }^{57} \text { Trainning on chronic } \\
\text { disease self-management. }\end{array}$ \\
\hline & $\begin{array}{l}\text { Training for } \\
\text { management of } \\
\text { people with dementia }\end{array}$ & 3 & $\begin{array}{l}\text { Verkaik et al, }{ }^{59} \text { Testad et } \\
\text { al, }{ }^{60} \text { Siddiqi et al }{ }^{61}\end{array}$ & $\begin{array}{l}\text { Depression guidelines for PWD, }{ }^{59} \text { Training } \\
\text { on agitation and restrain use for PWD, }{ }^{60} \\
\text { Staff training on delirium risk factors. }\end{array}$ \\
\hline & $\begin{array}{l}\text { Interventions aimed } \\
\text { at creating social } \\
\text { support networks }\end{array}$ & 2 & Wang et al, ${ }^{62}$ Chien et al ${ }^{63}$ & $\begin{array}{l}\text { Family-led mutual support group for } \\
\text { PWD, }{ }^{62} \text { Care programme for families of } \\
\text { PWD. }{ }^{63}\end{array}$ \\
\hline & $\begin{array}{l}\text { Training on } \\
\text { medication review }\end{array}$ & 2 & $\begin{array}{l}\text { García-Gollarte et al, }{ }^{64} \\
\text { Pitkälä et al }\end{array}$ & $\begin{array}{l}\text { Nursing home physician training on } \\
\text { inappropriate prescription, }{ }^{64} \text { Nurse training } \\
\text { on harmful medication. }{ }^{65}\end{array}$ \\
\hline & $\begin{array}{l}\text { Training for infection } \\
\text { prevention and } \\
\text { control measures }\end{array}$ & 2 & Yeung et $a l^{66}$ Ho et $a l^{67}$ & Hand hygiene intervention. ${ }^{66} 67$ \\
\hline & $\begin{array}{l}\text { Training for } \\
\text { promoting oral health }\end{array}$ & 1 & Poisson et $a l^{70}$ & $\begin{array}{l}\text { Nutritional and oral care training for nursing } \\
\text { home staff. }\end{array}$ \\
\hline & $\begin{array}{l}\text { Training to identifying } \\
\text { deterioration signs } \\
\text { in functioning } \\
\text { (cognition, mood, } \\
\text { vitality, mobility, } \\
\text { vision, hearing, etc.) } \\
\text { and its management } \\
\text { and referral }\end{array}$ & 1 & Little et $a l^{71}$ & $\begin{array}{l}\text { Training on identification and management } \\
\text { of deterioration in care home residents. }{ }^{71}\end{array}$ \\
\hline & $\begin{array}{l}\text { Training on violence } \\
\text { prevention and } \\
\text { detection }\end{array}$ & 1 & Teresi et $a l^{72}$ & $\begin{array}{l}\text { Staff training targeting resident-to-resident } \\
\text { elder mistreatment. }{ }^{72}\end{array}$ \\
\hline & $\begin{array}{l}\text { Training on palliative } \\
\text { care assessment }\end{array}$ & 2 & Bökberg et al ${ }^{73}$ & $\begin{array}{l}\text { Training on palliative care need } \\
\text { identification and symptom management } \\
\text { for staff in nursing home, }{ }^{73} \text { Goals of care to } \\
\text { improve decision making and palliative care } \\
\text { for PWAD. }{ }^{74}\end{array}$ \\
\hline & $\begin{array}{l}\text { Training to manage } \\
\text { pain }\end{array}$ & 1 & Rostad et al ${ }^{75}$ & $\begin{array}{l}\text { Training on pain assessment and analgesic } \\
\text { use on residents with severe dementia. }{ }^{75}\end{array}$ \\
\hline
\end{tabular}


Table 5 Continued

\begin{tabular}{lll}
\hline Subdomain & $\begin{array}{l}\text { Clustered } \\
\text { interventions }\end{array}$ & Fr \\
\hline Person- & Person-centred & 21 \\
centred & assessment and care & \\
assessment & plan development & \\
and care & & \\
planning & & \\
$(\mathrm{n}=3)$ & &
\end{tabular}

Case management, 16 coordination and timely referral to ensure patientcentred continuum care
Frequency of

appearance Reference

Tikkanen et al, ${ }^{76}$ Franse et al, ${ }^{77}$ Parsons et al, ${ }^{78}$ Leung et al, ${ }^{79}$ Daniels et al, ${ }^{80} \mathrm{De}$ Vriendt et al, ${ }^{81}$ de Kerimel et al, ${ }^{82}$ Featherstone, ${ }^{83}$

Li et al, ${ }^{84}$ Tikkanen et al, ${ }^{85}$ Ploeg et al, ${ }^{86}$ Bleijenberg et al, ${ }^{87}$ Hoogendijk et al, ${ }^{88}$ Monteserin et al, ${ }^{89}$ Godwin et al, ${ }^{90}$ Fairhall et al, ${ }^{91}$

Fairhall et al, ${ }^{92}$ Fairhall et al, ${ }^{93}$ Cameron et al, ${ }^{94}$ Lindquist et al, ${ }^{95}$ Chan and Pang ${ }^{96}$

Dolovich et al, ${ }^{97}$ Wilson and Bachman, ${ }^{98}$ Fleisher et al, ${ }^{99}$ Fristedt et al, ${ }^{100}$ Granbom et al, ${ }^{101}$ Szanton et al, ${ }^{102} \mathrm{Di}$ Pollina et $a l,{ }^{103}$ Melnick et al, ${ }^{104}$

Imhof et al, ${ }^{105}$ Kono et al, ${ }^{106}$ van Hout et al, ${ }^{107}$ Favela et al, ${ }^{108}$ Frese et al, ${ }^{109}$ Metzelthin et al, ${ }^{110}$ Bökberg et al, ${ }^{111}$ Jansen et al, ${ }^{112}$ Looman et al ${ }^{113}$.
Assessment of caregiver needs included in the person-centred assessment
8

Janse et al, ${ }^{112}$
Yu, ${ }^{114}$
Tanner et al, ${ }^{115}$
Radwany et al, ${ }^{116}$
Montgomery et al, ${ }^{117}$
Lam et al, ${ }^{118} \mathrm{Kwok}_{\text {et }}$ al, ${ }^{119}$
Tuntland $\mathrm{H}$ et al ${ }^{120}$

\section{Examples of included interventions*}

Comprehensive geriatric assessmentbased individually targeted interventions on mobility, ${ }^{76}$ Referral to social and health services based on a comprehensive geriatric assessment, ${ }^{77} 78$ 80-94 Persons centred assessment followed by care management service for the prevention of falls, ${ }^{79}$ Screening of needs for personal decisions regarding health support, home needs and care planning. ${ }^{95} 96$

Achieving health goals and covering older adults needs through volunteers and primary care support, ${ }^{97}$ House calls to support home-based care of PWD and PWA, ${ }^{98}$ Home visits for individuals with advanced Parkinson's Disease, ${ }^{99}$ Mobile geriatric teams, ${ }^{100}$ Case management to improve social participation and leisure activities, ${ }^{101}$ Behavioural and home repair interventions, ${ }^{102}$ Integrated care for older adults with chronic conditions, ${ }^{103}$ Home calls for home bound older adults, ${ }^{104}$ Advanced practice nurse in-home health consultation programme for communitydwelling older adults, ${ }^{105}$ Preventive home visit programme based on a systematic assessment of care needs, ${ }^{106}$ Nurse home visits, ${ }^{107} 108$ In-home preventive comprehensive geriatric assessment, ${ }^{109}$ Multidimensional assessment and care based on a tailor made treatment plan, ${ }^{110}$ Home visits for PWD, ${ }^{111}$ Case management for older adults with early symptoms of dementia, ${ }^{112}$ Integrated care model. ${ }^{113}$ Integrated and multidisciplinary care for older frail adults, ${ }^{112}$ Health and social collaborative case management to optimise the support given to caregivers of frail elderly adults, ${ }^{114}$ Communitybased dementia care coordination, ${ }^{115}$ Advance care planning for older adults including caregivers needs, ${ }^{116}$ Assessment of caregivers need and management of burden and depressive symptoms, ${ }^{117}$ Case management for people with mild dementia with optimisation of family resources and community mobilisation, ${ }^{118}$ Case management for older people with early dementia and to reduce caregiver burden, ${ }^{119}$ Reablement for communitydwelling older adults. ${ }^{120}$

*For details please see online supplemental annex 1 'Detailed interventions'.

PWD, People with dementia; PWA, People with Alzheimer; PWAD, People with advanced dementia. 


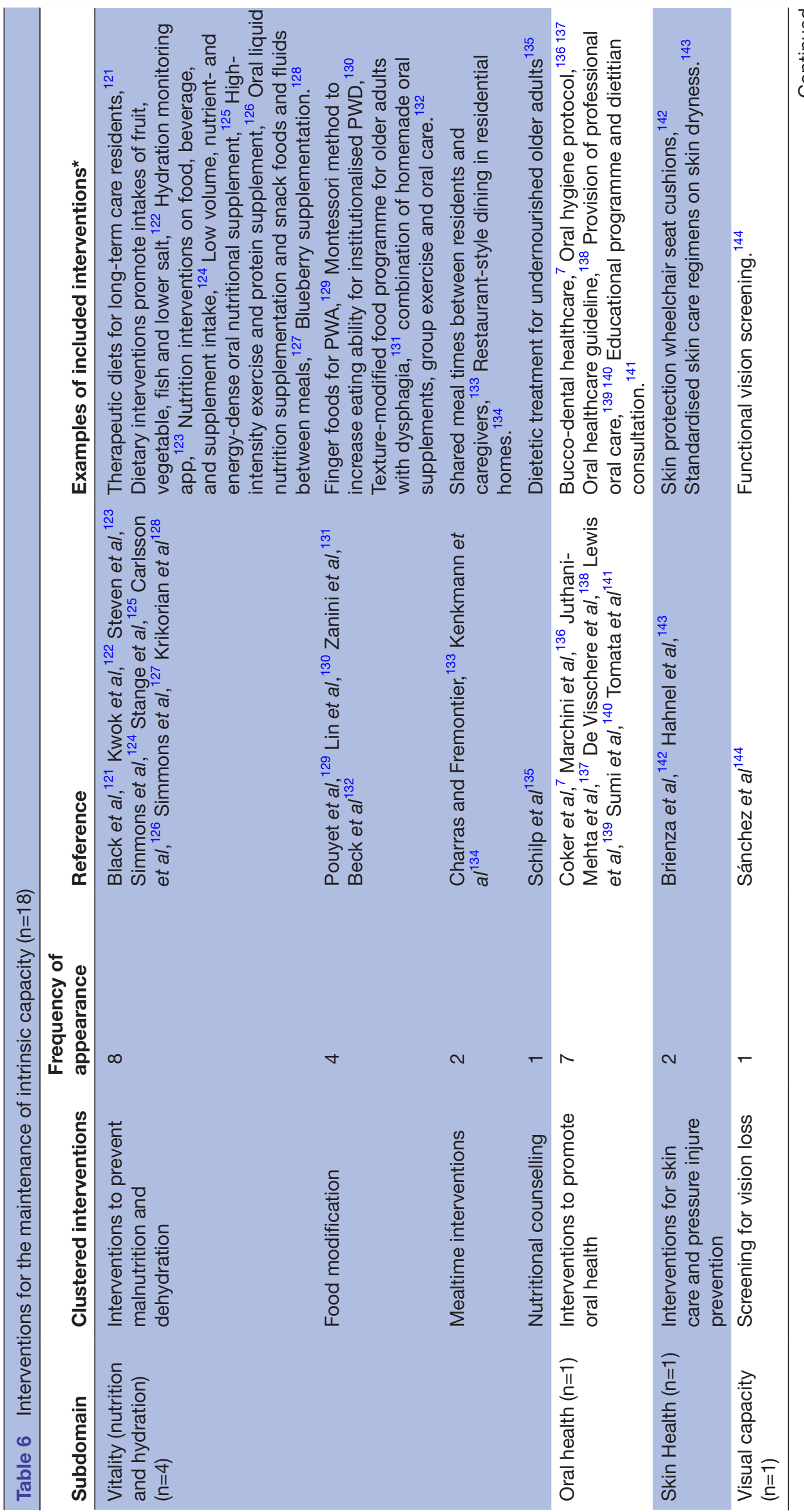




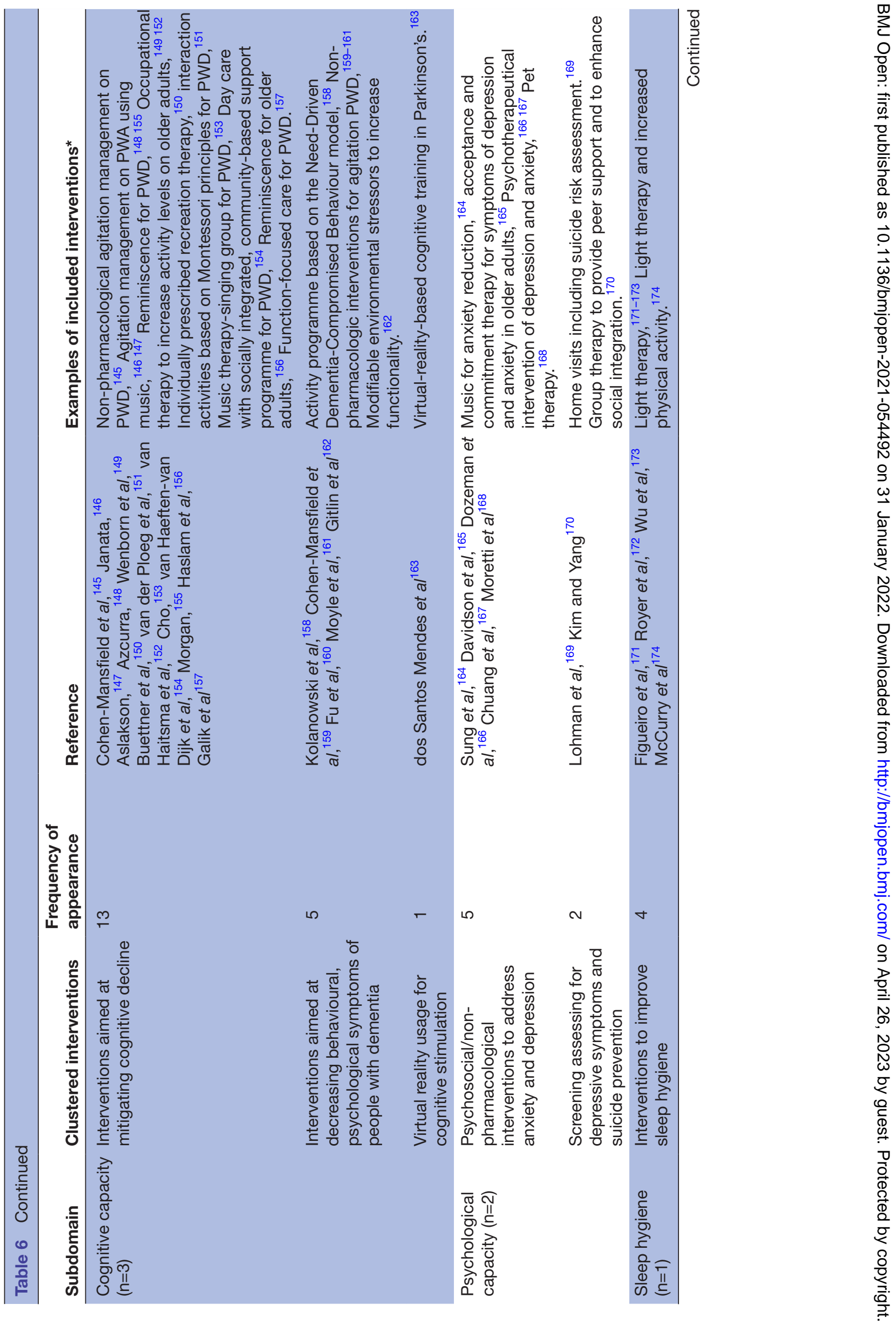


*

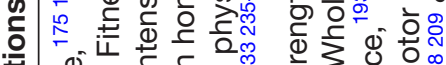

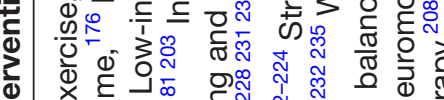

离

రำ

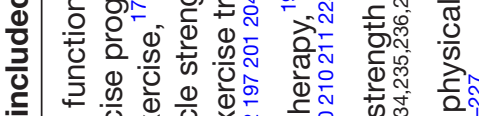

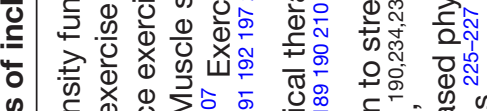

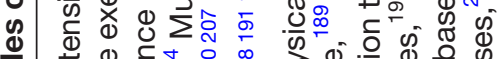

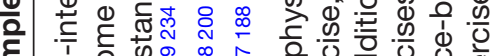

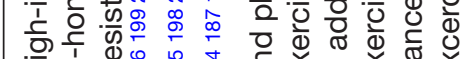

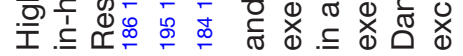

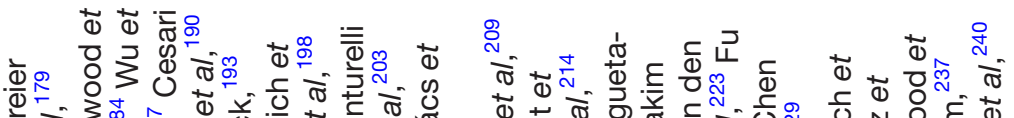

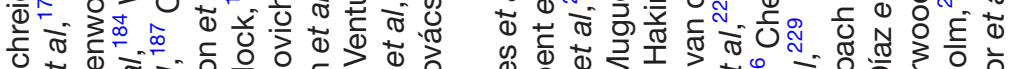

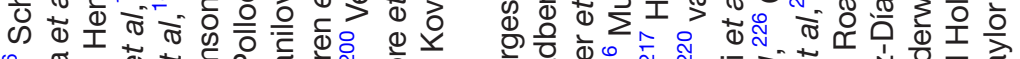

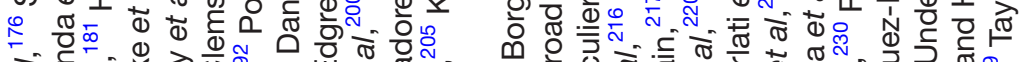

बं

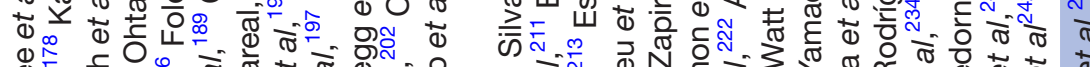

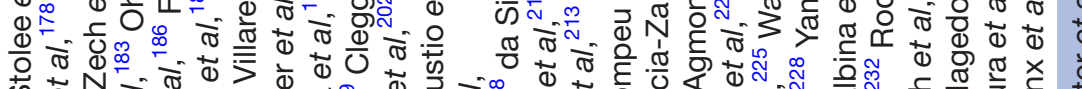

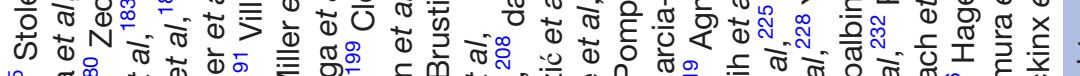

ผ बे

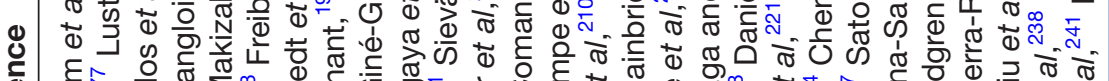

ब

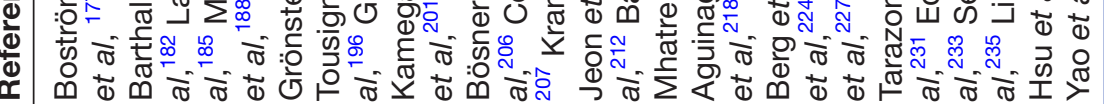

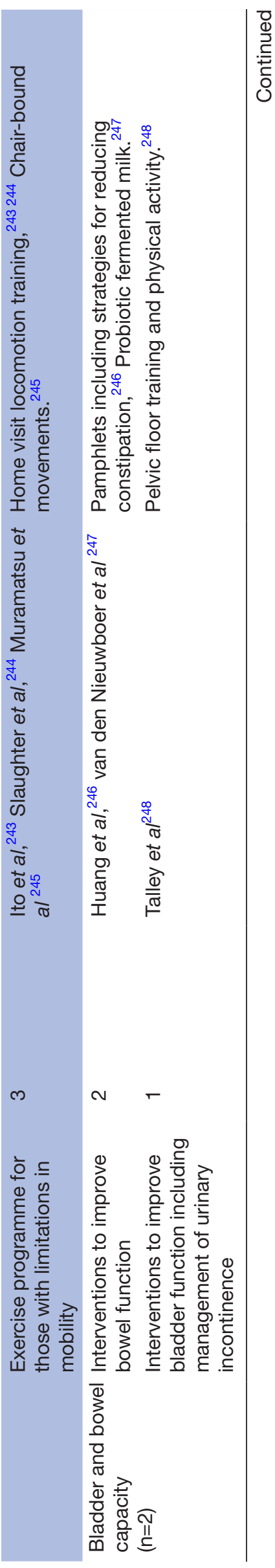




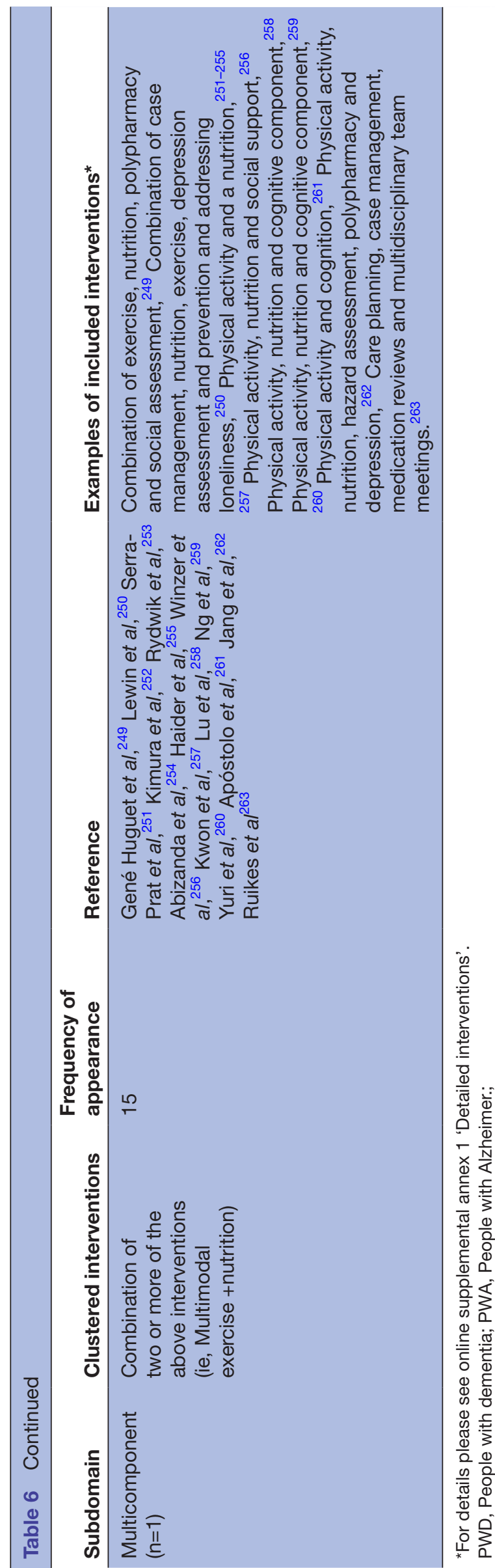

exercises to tackle loneliness and strive for a search of meaning and belonging. Specific non-pharmacological interventions targeting PWD were identified, these aimed at decreasing psychological and behavioural symptoms such as agitation, aggressiveness and depression. Another set of non-pharmacological interventions to promote mental health among older people was reported and included screening and appraisal of depression and anxiety, while only one aimed at preventing suicide. Sleep hygiene was reported in four studies, which aimed at improving the circadian rhythm by adding light therapy and structured day routines.

The multimodal exercise programme was recorded as the most frequently appearing intervention in this study $(n=68)$. These interventions mainly focused on giving older adults the possibility of engaging in physical activity and exercising with the aim of improving muscle power, strength, resistance and balance alone or in combination and on improving stretching. Interestingly, an increasing relevant role of exergames on older people's exercising was detected. Several studies reported on specific multimodal exercise interventions conducted through exergames. Similarly relevant were the multicomponent interventions, which mainly reported on combinations of multimodal exercises and nutritional interventions or those to improve cognition.

\section{Interventions for the optimisation of functional ability}

These interventions focused on the interactions between older people and their environment (table 7). Two studies targeted the mobility of older people in their community and proposed buddy-based programmes and volunteer based models to promote mobility. Other interventions within this domain aimed at maintaining older people's capacity of building and maintaining relationships by engaging in letter writing activities or reminiscence exercises on the search for meaning of their lives. Lastly, other studies targeted interventions to foster continued opportunities for learning, growing and decision-making. These were related workshops for the better understanding of ageing and disease, or interventions to strengthening older adult's capacity to move in an environment that they perceive as dangerous. Lastly, we identified one intervention using artificial intelligence in form of robots to address loneliness.

\section{Additional environmental and structural interventions}

Table 8 summarises the results for this thematic area. The environmental modifications of housing settings were reported. These targeted the modification of bathing facilities, changing flooring surfaces and lighting hallways. Only one study reported an older-young people combined housing model.

Fall preventions were often mentioned in the scientific literature. Interventions included a person-centred risk assessment to screen older people's risk and identify modifiable settings. Another set of interventions targeted 
Table 7 Interventions for the optimisation of functional ability $(n=4)$

\begin{tabular}{|c|c|c|c|c|}
\hline Subdomain & $\begin{array}{l}\text { Clustered } \\
\text { interventions }\end{array}$ & $\begin{array}{l}\text { Frequency of } \\
\text { appearance }\end{array}$ & Reference & Examples of included interventions* \\
\hline $\begin{array}{l}\text { Moving around } \\
(n=1)\end{array}$ & $\begin{array}{l}\text { Interventions to } \\
\text { promote mobility in } \\
\text { the community }\end{array}$ & 2 & $\begin{array}{l}\text { Clark et al, }{ }^{264} \text { Rantanen } \\
\text { et }\left.a\right|^{265}\end{array}$ & $\begin{array}{l}\text { Lifestyle modification and strategies to } \\
\text { overcome everyday obstacles, }{ }^{264} \text { Outdoor } \\
\text { activities to promote mobility and social } \\
\text { participation. }{ }^{265}\end{array}$ \\
\hline \multirow[t]{2}{*}{$\begin{array}{l}\text { Build and maintain } \\
\text { relationships }(n=2)\end{array}$} & $\begin{array}{l}\text { Interventions to } \\
\text { build and maintain } \\
\text { relationships }\end{array}$ & 4 & $\begin{array}{l}\text { Duyan et al, }{ }^{266} \text { Imai et } \\
\text { al, }{ }^{267} \text { Chochinov et al, } \\
\text { Tsai and Tsai }\end{array}$ & $\begin{array}{l}\text { Support group therapy, }{ }^{266} \text { Reception } \\
\text { of postcards from members of the } \\
\text { community, }{ }^{267} \text { Dignity therapy, }{ }^{268} \\
\text { Videoconferences wit family members. }{ }^{268}\end{array}$ \\
\hline & $\begin{array}{l}\text { Artificial intelligence } \\
\text { in form of robots } \\
\text { aimed at addressing } \\
\text { loneliness } \\
\text { and providing } \\
\text { companionship }\end{array}$ & 1 & Moyle et $a l^{270}$ & $\begin{array}{l}\text { Robotic Seal as a therapeutic tool to } \\
\text { tackle loneliness }\end{array}$ \\
\hline
\end{tabular}

*For details please see online supplemental annex 1 'Detailed interventions'.

cognitive interventions to manage older adults' fear of falling.

Interventions to prevent and control multiple, unnecessary medicine prescriptions seemed to be a field of interest within the scientific literature. Authors proposed various interventions to monitor polypharmacy at longterm care facilities, by including external pharmacist review on residents' prescriptions and enhancing interdisciplinary cooperation between physicians, nurses and pharmacists. One study proposed a primary care, at a home setting, approach to this issue by suggesting the external revision of older adults' prescriptions from a pharmacist. Vaccination interventions were reported in long-term care facilities, particularly against influenza and pneumonia.

Perhaps reflecting the search teams, only two studies addressed pain management and palliative and endof-life care. To address pain in older adults one study proposed hand-massage as an alternative therapy to alter pain perception. To provide timely palliative and endof-life care one study reported on home visits providing primary medical care from time of the enrolment in the programme with 24 hours availability and maintenance of close working relationships with community-based nursing and social service agencies, patients and their caregivers.

Lastly, several interventions involving technology or the use of technology as means to provide long-term care were reported. Although these interventions appeared in several subdomains, we decided to cluster all these interventions under one subdomain named digital health.
Rather than the type of support that they were using or the aimed they had, the common factor leading to clustarisation was the use of technology. These interventions aimed to provide cognitive stimulation and to store health information. As mentioned before, technology has also found its niche in multimodal exercise through exergames.

\section{DISCUSSION}

This study provides an overview of the identified interventions that have been evaluated and published in the scientific literature in the last 10 years. A total of 49 clusters using 273 formulations were identified, classified in relation to WHO's public health framework of healthy ageing in 20 subdomains. The interventions varied greatly between each other and represented different thematic areas, this resonates with the complex landscape of longterm care provision and the challenge of covering older adults multiple needs at various levels and settings. The categorisation following healthy ageing domains is a first attempt to understanding the field of research. As longterm care is a continuum of care rather than a categorical matter, the domains we propose at some points overlap.

Regarding the top reported interventions, they show a trend towards offering physical activity and exercise to older adults seeking to maintain functional ability, towards implementing person-centred care programmes and interventions, coordinating care, training caregivers and combining interventions such as physical activity an nutritional advice. As a matter of fact, the implementation 


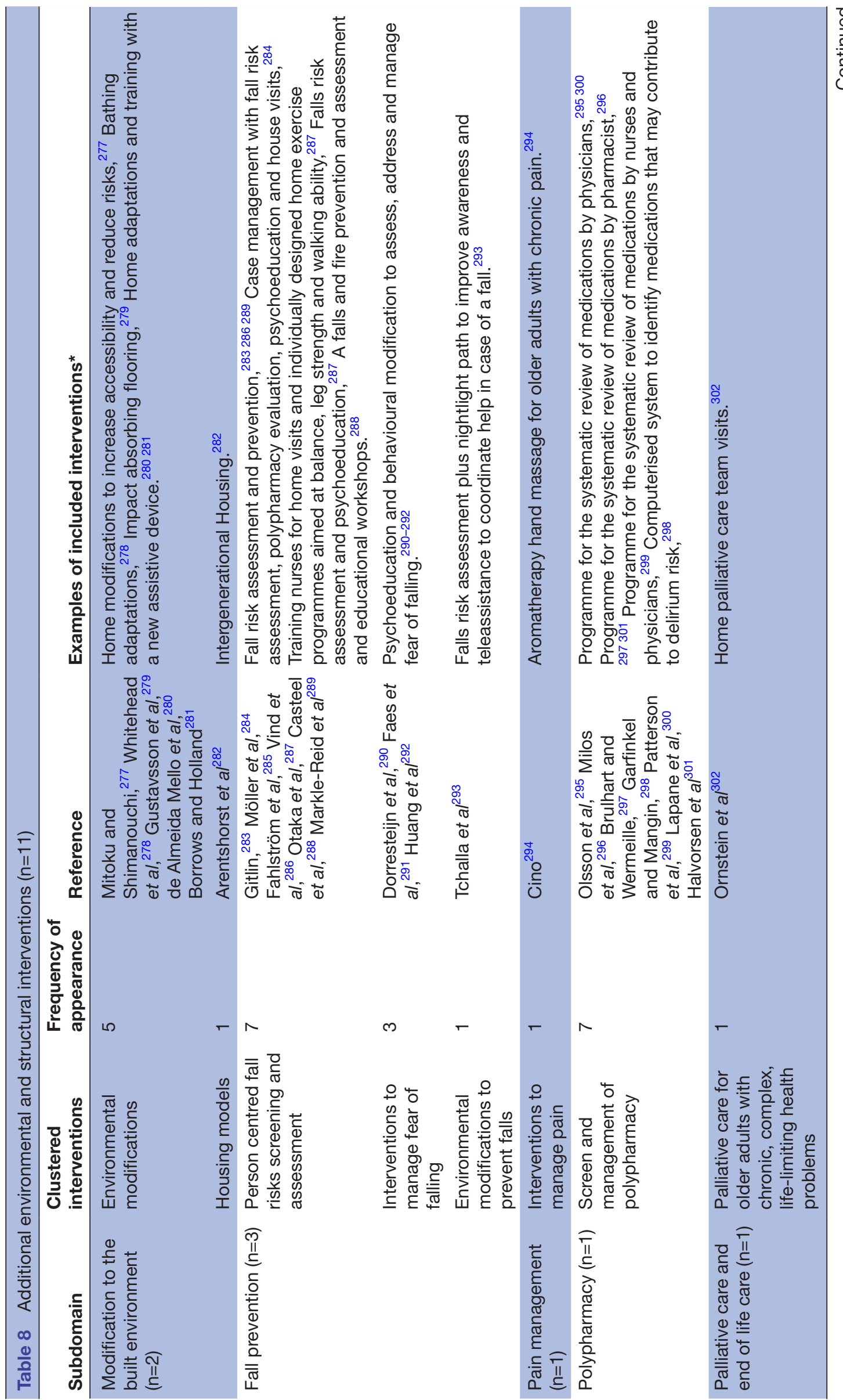




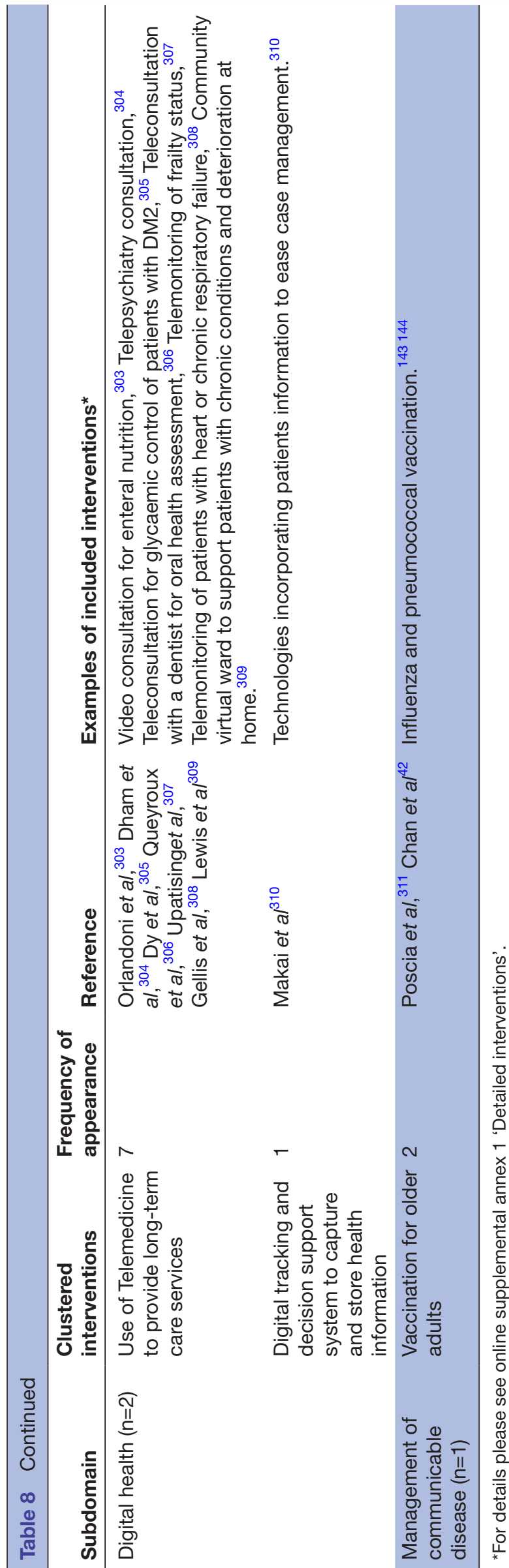

of comprehensive geriatric assessment appeared as overarching topic across the domains. This approach could be considered a preparatory step for long-term care service provision based on need. Our search strategy might have not been able to capture other long-term care interventions like food-on-wheels, management of incontinence and chronic disease management among others, thus such interventions are missing. In a next consultation step we will expose the interventions to long-term care and ageing experts to add missing interventions.

All the studies and interventions detected through our search strategy corresponded to those provided in HIC and UMCs. No interventions provided in lower-middleincome or low-income countries were identified. This under-representation can result from lack of resources to conduct research on these topics but definitely does not mean a lack of long-term care interventions in lowresource settings. Also important to consider is the fact that our search focused on international-overarching databases, we did not search regional databases were relevant local information might be stored. Therefore, the outcomes of this study represent the findings on global databases. Further research can target interventions published on regional databases.

According to the findings of this study, home, community and long-term care facilities account for the most frequent settings were this type of care is provided. Although interventions were more reported at institutional settings, long-term care transcends the barriers of facility and facility-like settings to the community and home. Communities should, therefore, be considered as a key setting for long-term care provision. Promoting greater access and sustainable costs, can be particularly helpful to expand coverage of services within a country's benefit packages implementing Universal Health Coverage and ensuring close proximity to primary care. ${ }^{41}$ However, a common or agreed definition for 'settings' was not provided. This study's scope focused only on collecting the settings as reported in the studies and did not strive to harmonise the definition of settings.

WHO's programme on integrated care for older people (ICOPE $)^{35}$ has done extensive work to move away from disease based approaches and look into interventions that optimise intrinsic capacity. The retrieved interventions from the scoping review for long-term care have shown to be inclusive of those interventions for the ICOPE guidelines, ${ }^{35}$ highlighting the relevance of integrated care within long-term care services.

However, this study revealed gaps in potential important long-term care interventions. Out of the six important domains of intrinsic capacity (vitality, locomotor capacity, psychological capacity, cognitive capacity, visual capacity, hearing capacity) ${ }^{35}$ no specific interventions for hearing capacity was identified. Furthermore, functional ability is about having the capabilities that enable all people to be and do what they have reason to value. This includes a person's ability to meet their basic needs; learn, grow and make decisions; be mobile; build and maintain 
relationships; and contribute to society. ${ }^{2}$ After a categorisation of the interventions retrieved, we found that still there was a substantial gap of interventions addressing basic needs, including social care and support services, and interventions that enhance societal contribution.

\section{Weaknesses}

This study followed a scoping review design to provide an overview of the existing evidence on the topic and did not include risk bias assessment or formal assessment of methodological quality. Risk bias assessment is usually not conducted on scoping reviews. ${ }^{35} 36$

Additionally, the scope of this study did not include a quality appraisal or analysis of their outcomes. Therefore, results only depict the domains and subdomains where the interventions could be categorised. The numerous outcome parameters, various settings and different populations reduced the comparability of studies. Additionally, data disaggregation by sex and age groups was not possible since many studies missed this information. Better disaggregation would broaden the understanding of the population receiving long-term care.

\section{Further research}

This study attempted a categorising of long-term care interventions in relation to WHO's public health framework of healthy ageing. Further research needs to be conducted to design an improved categorisation and should ideally need to include the voices of academic and policy experts on the field, and older adults. ${ }^{42}$ The lowresource setting under-representation needs to be tackled by including specific interventions from this settings. This finding highlights the need to support research efforts and capacity building strategies in under-represented settings to translate long-term care traditional provision into scientific literature. It also demands the attention from research groups, decision-makers and other stakeholders to thoroughly consider long-term care interventions locally provided, and not reported, as sources of crucial information on long-term care provision and coverage.

Further research is required to incorporate the vision and practices of various settings regarding the provision of long-term care interventions (eg, at the community level). In the case of using this list for informed decision making, consensus processes or as a repository of interventions, special attention has to be given to the cultural, regional applicability of the here included interventions in specific contexts.

Further research should address equity issues more broadly to include focus on addressing specific long-term care needs to optimise functional ability and achieve healthy ageing in specific under-represented populations.

\footnotetext{
Author affiliations

${ }^{1}$ ATLANTES Global Observatory for Palliative Care, University of Navarra, Pamplona, Spain

${ }^{2}$ Maternal, Newborn, Child and Adolescent Health and Ageing, World Health Organization, Geneva, Switzerland
}

${ }^{3}$ City of Sao Paulo University, Sao Paulo, Brazil

${ }^{4}$ College of Nursing, Jeju National University, Jeju, Republic of Korea

${ }^{5}$ Department of Family Medicine and Chronic Care, Vrije Universiteit Brussel,

Brussels, Belgium

${ }^{6}$ End-of-Life Care Research Group, Vrije Universiteit Brussel, Brussels, Belgium

Contributors NA-C and ZH designed and conducted this study, ATJ, MRP, EP and $\mathrm{LVdB}$ provided technical advice on the study design. ATJ and MRP supported with data analysis and categorisation. NA-C, ZH, ATJ and MRP drafted the article. RS, EP, $\mathrm{LVdB}, Y S$ and $A B$ revised the manuscript, provided technical advice and suggestions. $A B$ and $Z H$ are joint last authors. $Z H$ is the author acting as guarantor.

Funding This study was made possible by funding provided to WHO by the Republic of Korea, Ministry of Health and Welfare. Grant number: 70928.

Competing interests None declared.

Patient consent for publication Not applicable.

Provenance and peer review Not commissioned; externally peer reviewed.

Data availability statement Data are available on reasonable request. All data relevant to the study are included in the article or uploaded as online supplemental information. Besides being included in the article as an Annex, data regarding this study are available on request mperracini@who.it.

Supplemental material This content has been supplied by the author(s). It has not been vetted by BMJ Publishing Group Limited (BMJ) and may not have been peer-reviewed. Any opinions or recommendations discussed are solely those of the author(s) and are not endorsed by BMJ. BMJ disclaims all liability and responsibility arising from any reliance placed on the content. Where the content includes any translated material, BMJ does not warrant the accuracy and reliability of the translations (including but not limited to local regulations, clinical guidelines, terminology, drug names and drug dosages), and is not responsible for any error and/or omissions arising from translation and adaptation or otherwise.

Open access This is an open access article distributed in accordance with the Creative Commons Attribution Non Commercial (CC BY-NC 4.0) license, which permits others to distribute, remix, adapt, build upon this work non-commercially, and license their derivative works on different terms, provided the original work is properly cited, appropriate credit is given, any changes made indicated, and the use is non-commercial. See: http://creativecommons.org/licenses/by-nc/4.0/.

ORCID iDs

Natalia Arias-Casais http://orcid.org/0000-0001-6979-293X

Zee-A Han http://orcid.org/0000-0002-8070-2218

\section{REFERENCES}

1 United Nations, Department of Economic and Social Affairs, Population Division. World population ageing 2019 (ST/ESA/ SER.A/444), 2020. Available: https://www.un.org/en/development/ desa/population/publications/pdf/ageing/WorldPopulationAgein g2019-Report.pdf

2 World Health Organization. World report on ageing and health.

3 Scheil-Adlung X. Long-term care protection for older persons: a review of coverage deficits in 46 countries 2015.

4 Colombo F, Llena-Nozal A, Mercier JTF. Help wanted? Providing and paying for long-term care. organization for economic cooperation and development 2011.

5 World Health Organization. Towards long-term care systems in subSaharan Africa: WHO series on long-term care. Geneva, 2017.

6 Fu L, Sun Z, He L, et al. Global long-term care research: a Scientometric review. Int J Environ Res Public Health 2019;16:16.

7 Coker E, Ploeg J, Kaasalainen S. The effect of programs to improve oral hygiene outcomes for older residents in long-term care: a systematic review. Res Gerontol Nurs 2014;7:87-100.

8 Wu B, Petrovsky DV, Wang J, et al. Dementia caregiver interventions in Chinese people: a systematic review. J Adv Nurs 2019;75:528-42.

9 Puts MTE, Toubasi S, Andrew MK, et al. Interventions to prevent or reduce the level of frailty in community-dwelling older adults: a scoping review of the literature and international policies. Age Ageing 2017;46:383-92.

10 Woodhouse R, Burton JK, Rana N, et al. Interventions for preventing delirium in older people in institutional long-term care. Cochrane Database Syst Rev 2019;4:CD009537. 
11 Van't Leven N, Prick A-EJC, Groenewoud JG, et al. Dyadic interventions for community-dwelling people with dementia and their family caregivers: a systematic review. Int Psychogeriatr 2013;25:1581-603.

12 Abdelhamid A, Bunn D, Copley M, et al. Effectiveness of interventions to directly support food and drink intake in people with dementia: systematic review and meta-analysis. BMC Geriat 2016;16:26

13 Travers C, Brooks D, Hines S, et al. Effectiveness of meaningful occupation interventions for people living with dementia in residential aged care: a systematic review. JBI Database System Rev Implement Rep 2016;14:163-225.

14 Möhler R, Renom A, Renom H, et al. Personally tailored activities for improving psychosocial outcomes for people with dementia in long-term care. Cochrane Database Syst Rev 2018;2:CD009812.

15 Bash E. Telemedicine Consultations for Patients in Long Term Care: A Review of Clinical Effectiveness, Cost - Effectiveness, and Guidelines. PhD Propos 2015;1.

16 Frost $\mathrm{R}$, Belk C, Jovicic A, et al. Health promotion interventions for community-dwelling older people with mild or pre-frailty: a systematic review and meta-analysis. BMC Geriatr 2017;17:157.

17 Silva CRDT, Carvalho KMde, Figueiredo MdoLF, et al. Health promotion of frail elderly individuals and at risk of frailty. Rev Bras Enferm 2019;72:319-327.

18 Liimatta H, Lampela P, Laitinen-Parkkonen P, et al. Effects of preventive home visits on older people's use and costs of health care services: A systematic review. Eur Geriatr Med 2016;7:571-80.

19 Cao P-Y, Zhao Q-H, Xiao M-Z, et al. The effectiveness of exercise for fall prevention in nursing home residents: a systematic review meta-analysis. J Adv Nurs 2018;74:2511-22.

20 Dedeyne L, Deschodt M, Verschueren S, et al. Effects of multidomain interventions in (pre)frail elderly on frailty, functional, and cognitive status: a systematic review. Clin Interv Aging 2017:12:873-96.

21 Whitehead PJ, Worthington EJ, Parry RH, et al. Interventions to reduce dependency in personal activities of daily living in community dwelling adults who use homecare services: a systematic review. Clin Rehabil 2015;29:1064-76.

22 Abbott RA, Whear R, Thompson-Coon J, et al. Effectiveness of mealtime interventions on nutritional outcomes for the elderly living in residential care: a systematic review and meta-analysis. Ageing Res Rev 2013;12:967-81.

23 Fritz H, Seidarabi S, Barbour R, et al. Occupational therapy intervention to improve outcomes among frail older adults: a scoping review. Am J Occup Ther 2019;73:1-13.

24 van Rijckevorsel-Scheele J, Willems RCWJ, Roelofs PDDM, et al. Effects of health care interventions on quality of life among frail elderly: a Systematized review. Clin Interv Aging 2019;14:643-58.

25 Liu C-ju, Chang W-P, Chang MC. Occupational therapy interventions to improve activities of daily living for communitydwelling older adults: a systematic review. Am J Occup Ther 2018;72:7204190060

26 Cadore EL, Rodríguez-Mañas L, Sinclair A, et al. Effects of different exercise interventions on risk of falls, gait ability, and balance in physically frail older adults: a systematic review. Rejuvenation Res 2013;16:105-14.

27 Giné-Garriga M, Roqué-Fíguls M, Coll-Planas L, et al. Physical exercise interventions for improving performance-based measures of physical function in community-dwelling, frail older adults: a systematic review and meta-analysis. Arch Phys Med Rehabil 2014:95:753-69.

28 de Labra C, Guimaraes-Pinheiro C, Maseda A, et al. Effects of physical exercise interventions in frail older adults: a systematic review of randomized controlled trials. BMC Geriatr 2015;15:154.

29 Haider S, Grabovac I, Dorner TE. Effects of physical activity interventions in frail and prefrail community-dwelling people on frailty status, muscle strength, physical performance and muscle mass-a narrative review. Wien Klin Wochenschr 2019;131:244-54.

30 Tjia J, Velten SJ, Parsons C, et al. Studies to reduce unnecessary medication use in frail older adults: a systematic review. Drugs Aging 2013;30:285-307.

31 Cochrane A, Furlong M, McGilloway S, et al. Time-limited homecare reablement services for maintaining and improving the functional independence of older adults. Cochrane Database Syst Rev 2016;10:CD010825.

32 Forsetlund L, Eike MC, Gjerberg E, et al. Effect of interventions to reduce potentially inappropriate use of drugs in nursing homes: a systematic review of randomised controlled trials. BMC Geriatr 2011;11:16.
33 Veras RP, Caldas CP, Motta LBda, et al. Integration and continuity of care in health care network models for frail older adults. Rev Saude Publica 2014;48:357-65

34 Béland F, Hollander MJ. Integrated models of care delivery for the frail elderly: international perspectives. Gac Sanit 2011;25(Suppl 2):138-46.

35 World Health Organization. Integrated care for older people: guidelines on community-level interventions to manage declines in intrinsic capacity. Geneva, 2017. https://www.who.int/ageing/ publications/guidelines-icope/en/

36 Peters MDJ, Godfrey CM, Khalil H, et al. Guidance for conducting systematic scoping reviews. Int J Evid Based Healthc 2015;13:141-6

37 Tricco AC, Lillie E, Zarin W, et al. PRISMA extension for scoping reviews (PRISMA-ScR): checklist and explanation. Ann Intern Med 2018;169:467-73.

38 Moher D, Liberati A, Tetzlaff J, et al. Preferred reporting items for systematic reviews and meta-analyses: the PRISMA statement. PLoS Med 2009;6:e1000097.

39 Fu L, Sun Z, He L, et al. Global long-term care research: a Scientometric review. Int J Environ Res Public Health 2019;16. doi:10.3390/ijerph16122077. [Epub ahead of print: 1206 2019].

40 World Bank. World bank country and lending groups. 2020.

41 World Health Organization (WHO). Astana Declaration on primary health care: from Alma-Ata towards universal health coverage and the sustainable development goals, 2018.

42 Chan T-C, Hung IF-N, Luk JK-H, et al. Prevention of mortality and pneumonia among nursing home older adults by dual pneumococcal and seasonal influenza vaccination during a pandemic caused by novel pandemic influenza A (H1N1). J Am Med Dir Assoc 2012;13:698-703.

43 Jalali S, Wohlin C. Systematic literature studies: database searches vs. backward snowballing. International Symposium on Empirical Software Engineering and Measurement, 2012:29-38.

44 Cheng S-T, Lau RWL, Mak EPM, et al. Benefit-finding intervention for Alzheimer caregivers: conceptual framework, implementation issues, and preliminary efficacy. Gerontologist 2014;54:1049-58.

45 Chu H, Yang C-Y, Liao Y-H, Chen C, et al. The effects of a support group on dementia caregivers' burden and depression. J Aging Health 2011;23:228.

46 Wang L-Q, Chien W-T, Lee IYM. An experimental study on the effectiveness of a mutual support group for family caregivers of a relative with dementia in mainland China. Contemp Nurse 2012;40:210-24.

$47 \mathrm{Au} \mathrm{A}$, Li S, Lee K, et al. The coping with caregiving group program for Chinese caregivers of patients with Alzheimer's disease in Hong Kong. Patient Educ Couns 2010;78:256-60.

48 Kwok T, Wong B, Ip I, et al. Telephone-delivered psychoeducational intervention for Hong Kong Chinese dementia caregivers: a single-blinded randomized controlled trial. Clin Interv Aging 2013;8:1191-7.

49 Chen H-M, Huang M-F, Yeh Y-C, et al. Effectiveness of coping strategies intervention on caregiver burden among caregivers of elderly patients with dementia. Psychogeriatrics 2015;15:20-5.

50 Au A. Developing Volunteer-Assisted behavioral activation Teleprograms to meet the needs of Chinese dementia caregivers. Clin Gerontol 2015;38:190-202.

51 Kwok T, Au A, Wong B, et al. Effectiveness of online cognitive behavioral therapy on family caregivers of people with dementia. Clin Interv Aging 2014;9:631-6.

52 Velásquez V, López L, López $\mathrm{H}$, et al. [The effect of an elderly people caregivers' educational program: a cultural perspective]. Rev Salud Publica 2011;13:458-69.

53 Au A, Wong MK, Leung LM, et al. Telephone-assisted pleasantevent scheduling to enhance well-being of caregivers of people with dementia: a randomised controlled trial. Hong Kong Med $J$ 2014;20:S30-3.

54 Cooper C, Barber J, Griffin M, et al. Effectiveness of start psychological intervention in reducing abuse by dementia family carers: randomized controlled trial. Int Psychogeriatr 2016;28:8817.

55 Logsdon RG, Pike KC, McCurry SM, et al. Early-Stage memory loss support groups: outcomes from a randomized controlled clinical trial. J Gerontol B Psychol Sci Soc Sci 2010;65:69.

56 Huang H-L, Kuo L-M, Chen Y-S, et al. A Home-Based Training Program Improves Caregivers' Skills and Dementia Patients' Aggressive Behaviors: A Randomized Controlled Trial. The American Journal of Geriatric Psychiatry 2013;21:1060-70.

57 Simmons SF, Hollingsworth EK, Long EA, et al. Training Nonnursing staff to assist with nutritional care delivery in nursing homes: a costeffectiveness analysis. J Am Geriatr Soc 2017;65:313-22. 
58 Ford $\mathrm{JH}$, Abramson $\mathrm{B}$, Wise $\mathrm{M}$, et al. Bringing healthy aging to scale: a randomized trial of a quality improvement intervention to increase adoption of evidence-based health promotion programs by community partners. J Public Health Manag Pract 2017;23:e17-24.

59 Verkaik R, Francke AL, van Meijel B, et al. The effects of a nursing guideline on depression in psychogeriatric nursing home residents with dementia. Int J Geriatr Psychiatry 2011;26:723-32.

60 Testad I, Ballard C, Brønnick K, et al. The effect of staff training on agitation and use of restraint in nursing home residents with dementia: a single-blind, randomized controlled trial. J Clin Psychiatry 2010;71:80-6.

61 Siddiqi N, Cheater F, Collinson M, et al. The PiTSTOP study: a feasibility cluster randomized trial of delirium prevention in care homes for older people. Age Ageing 2016;45:651-60.

62 Wang L-Q, Chien W-T, Wang LCW. Randomised controlled trial of a family-led mutual support programme for people with dementia. $J$ Clin Nurs 2011;20:2362-6.

63 Chien WT, Lee IYM, i CWL. Randomized controlled trial of a dementia care programme for families of home-resided older people with dementia. J Adv Nurs 2011;67:774-87.

64 García-Gollarte F, Baleriola-Júlvez J, Ferrero-López I, et al. An educational intervention on drug use in nursing homes improves health outcomes resource utilization and reduces inappropriate drug prescription. J Am Med Dir Assoc 2014;15:885-91.

65 Pitkälä KH, Juola A-L, Kautiainen H, et al. Education to reduce potentially harmful medication use among residents of assisted living facilities: a randomized controlled trial. J Am Med Dir Assoc 2014;15:892-8.

66 Yeung WK, Tam WSW, Wong TW. Clustered randomized controlled trial of a hand hygiene intervention involving pocketsized containers of alcohol-based hand rub for the control of infections in long-term care facilities. Infect Control Hosp Epidemiol 2011;32:67-76.

67 Ho M-lin, Seto W-hong, Wong L-chin, et al. Effectiveness of multifaceted hand hygiene interventions in long-term care facilities in Hong Kong: a cluster-randomized controlled trial. Infect Control Hosp Epidemiol 2012;33:761-7.

68 Lorefält B, Wilhelmsson S. A multifaceted intervention model can give a lasting improvement of older peoples' nutritional status. $J$ Nutr Health Aging 2012;16:378-82.

69 Stern A, Mitsakakis N, Paulden M, et al. Pressure ulcer multidisciplinary teams via telemedicine: a pragmatic cluster randomized stepped wedge trial in long term care. BMC Health Serv Res 2014;14:1-13.

70 Poisson P, Barberger-Gateau P, Tulon A, et al. Efficiency at the resident's level of the NABUCCOD nutrition and oral health care training program in nursing homes. J Am Med Dir Assoc 2014;15:290-5.

71 Little S, Rodgers G, Fitzpatrick JM. Managing deterioration in older adults in care homes: a quality improvement project to introduce an early warning tool. Br J Community Nurs 2019;24:58-66

72 Teresi JA, Ramirez M, Ellis J, et al. A staff intervention targeting resident-to-resident elder mistreatment (R-REM) in long-term care increased staff knowledge, recognition and reporting: results from a cluster randomized trial. Int J Nurs Stud 2013;50:644-56.

73 Bökberg C, Behm L, Ahlström G. Quality of life of older persons in nursing homes after the implementation of a knowledge-based palliative care intervention. Int J Older People Nurs 2019;14:1-11.

74 Hanson LC, Zimmerman S, Song M-K, et al. Effect of the goals of care intervention for advanced dementia: a randomized clinical trial. JAMA Intern Med 2017;177:24-31.

75 Rostad HM, Utne I, Grov EK, et al. The impact of a pain assessment intervention on pain score and analgesic use in older nursing home residents with severe dementia: a cluster randomised controlled trial. Int J Nurs Stud 2018;84:52-60.

76 Tikkanen P, Lönnroos E, Sipilä S, et al. Effects of comprehensive geriatric assessment-based individually targeted interventions on mobility of pre-frail and frail community-dwelling older people. Geriatr Gerontol Int 2015;15:80-8.

77 Franse CB, van Grieken A, Alhambra-Borrás T, et al. The effectiveness of a coordinated preventive care approach for healthy ageing (UHCE) among older persons in five European cities: a prepost controlled trial. Int J Nurs Stud 2018;88:153-62.

78 Parsons M, Senior H, Kerse N, et al. Randomised trial of restorative home care for frail older people in New Zealand. Nurs Older People 2017;29:27-33.

79 Leung AYM, Lou VWQ, Chan KS, et al. Care management service and falls prevention: a case-control study in a Chinese population. $J$ Aging Health 2010;22:348-61.
80 Daniels R, van Rossum E, Metzelthin S, et al. A disability prevention programme for community-dwelling frail older persons. Clin Rehabil 2011;25:963-74.

81 De Vriendt P, Peersman W, Florus A, et al. Improving health related quality of life and independence in community dwelling frail older adults through a client-centred and activity-oriented program. A pragmatic randomized controlled trial. J Nutr Health Aging 2016;20:35-40.

82 de Kerimel J, Tavassoli N, Lafont C, et al. How to manage frail older adults in the community? Proposal of a health promotion program experienced in a city of 16,638 inhabitants in France. J Frailty Aging 2018:7:120-6.

83 Featherstone A. Developing a holistic, multidisciplinary community service for frail older people. Nurs Older People 2018;30:1-7.

$84 \mathrm{Li} \mathrm{C}-\mathrm{M}$, Chen C-Y, Li C-Y, et al. The effectiveness of a comprehensive geriatric assessment intervention program for frailty in community-dwelling older people: a randomized, controlled trial. Arch Gerontol Geriatr 2010;50(Suppl 1):S39-42.

85 Tikkanen P, Lönnroos E, Sipilä S, et al. Effects of comprehensive health assessment and targeted intervention on chair rise capacity in active and inactive community-dwelling older people. Gerontology 2013;59:324-7.

86 Ploeg J, Brazil K, Hutchison B, et al. Effect of preventive primary care outreach on health related quality of life among older adults at risk of functional decline: randomised controlled trial. BMJ 2010;340:c1480.

87 Bleijenberg N, Drubbel I, Schuurmans MJ, et al. Effectiveness of a proactive primary care program on preserving daily functioning of older people: a cluster randomized controlled trial. J Am Geriatr Soc 2016;64:1779-88.

88 Hoogendijk EO, van der Horst HE, van de Ven PM, et al. Effectiveness of a geriatric care model for frail older adults in primary care: results from a stepped wedge cluster randomized trial. Eur J Intern Med 2016;28:43-51.

89 Monteserin R, Brotons C, Moral I, et al. Effectiveness of a geriatric intervention in primary care: a randomized clinical trial. Fam Pract 2010;27:239-45.

90 Godwin M, Gadag V, Pike A, et al. A randomized controlled trial of the effect of an intensive 1-year care management program on measures of health status in independent, community-living old elderly: the eldercare project. Fam Pract 2016;33:37-41.

91 Fairhall N, Sherrington C, Cameron ID, et al. A multifactorial intervention for frail older people is more than twice as effective among those who are compliant: complier average causal effect analysis of a randomised trial. J Physiother 2017;63:40-4.

92 Fairhall N, Sherrington C, Kurrle SE, et al. Economic evaluation of a multifactorial, interdisciplinary intervention versus usual care to reduce frailty in frail older people. J Am Med Dir Assoc 2015;16:41-8.

93 Fairhall N, Sherrington C, Kurrle SE, et al. Effect of a multifactorial interdisciplinary intervention on mobility-related disability in frail older people: randomised controlled trial. BMC Med 2012;10:120.

94 Cameron ID, Fairhall N, Langron C, et al. A multifactorial interdisciplinary intervention reduces frailty in older people: randomized trial. BMC Med 2013;11:65.

95 Lindquist LA, Ramirez-Zohfeld V, Sunkara PD, et al. PlanYourLifeSpan.org - an intervention to help seniors make choices for their fourth quarter of life: Results from the randomized clinical trial. Patient Educ Couns 2017:100:1996-2004.

96 Chan HYL, Pang SMC. Let me talk--an advance care planning programme for frail nursing home residents. J Clin Nurs 2010;19:3073-84

97 Dolovich L, Oliver D, Lamarche L, et al. Combining volunteers and primary care teamwork to support health goals and needs of older adults: a pragmatic randomized controlled trial. CMAJ 2019;191:E491-500.

98 Wilson K, Bachman SS. House calls: the impact of home-based care for older adults with Alzheimer's and dementia. Soc Work Health Care 2015;54:547-58.

99 Fleisher J, Barbosa W, Sweeney MM, et al. Interdisciplinary home visits for individuals with advanced Parkinson's disease and related disorders. J Am Geriatr Soc 2018;66:1226-32.

100 Fristedt S, Nystedt P, Skogar Örjan, . Mobile Geriatric Teams - A Cost-Effective Way Of Improving Patient Safety And Reducing Traditional Healthcare Utilization Among The Frail Elderly? A Randomized Controlled Trial. Clin Interv Aging 2019;14:1911-24.

101 Granbom M, Kristensson J, Sandberg M. Effects on leisure activities and social participation of a case management intervention for frail older people living at home: a randomised controlled trial. Health Soc Care Community 2017;25:1416-29. 
102 Szanton SL, Thorpe RJ, Boyd C, et al. Community aging in place, advancing better living for elders: a bio-behavioral-environmental intervention to improve function and health-related quality of life in disabled older adults. J Am Geriatr Soc 2011;59:2314-20.

103 Di Pollina L, Guessous I, Petoud V, et al. Integrated care at home reduces unnecessary hospitalizations of community-dwelling frail older adults: a prospective controlled trial. BMC Geriatr 2017; 17:1-10.

104 Melnick BGA, Green L, Rich J. House Calls : California Program. Health Aff 2016;1:28-35.

105 Imhof L, Naef R, Wallhagen Ml, et al. Effects of an advanced practice nurse in-home health consultation program for community-dwelling persons aged 80 and older. J Am Geriatr Soc 2012;60:2223-31.

106 Kono A, Izumi K, Yoshiyuki N, et al. Effects of an updated preventive home visit program based on a systematic structured assessment of care needs for ambulatory frail older adults in Japan: a randomized controlled trial. J Gerontol A Biol Sci Med Sci 2016;71:1631-7.

107 van Hout HPJ, Jansen APD, van Marwijk HWJ, et al. Prevention of adverse health trajectories in a vulnerable elderly population through nurse home visits: a randomized controlled trial [ISRCTN05358495]. J Gerontol A Biol Sci Med Sci 2010;65:734-42.

108 Favela J, Castro LA, Franco-Marina F, et al. Nurse home visits with or without alert buttons versus usual care in the frail elderly: a randomized controlled trial. Clin Interv Aging 2013;8:85-95.

109 Frese T, Deutsch T, Keyser M, et al. In-home preventive comprehensive geriatric assessment (CGA) reduces mortality--a randomized controlled trial. Arch Gerontol Geriatr 2012;55:639-44.

110 Metzelthin SF, van Rossum E, de Witte LP, et al. Effectiveness of interdisciplinary primary care approach to reduce disability in community dwelling frail older people: cluster randomised controlled trial. BMJ 2013;347:f5264.

111 Bökberg C, Ahlström G, Leino-Kilpi $\mathrm{H}$, et al. Care and service at home for persons with dementia in Europe. J Nurs Scholarsh 2015;47:407-16.

112 Jansen APD, van Hout HPJ, Nijpels G, et al. Effectiveness of case management among older adults with early symptoms of dementia and their primary informal caregivers: a randomized clinical trial. Int J Nurs Stud 2011;48:933-43.

113 Looman WM, Fabbricotti IN, Huijsman R. The short-term effects of an integrated care model for the frail elderly on health, quality of life, health care use and satisfaction with care. Int J Integr Care 2014;14:1-13.

114 Yu DSF. Effects of a health and social collaborative case management model on health outcomes of family caregivers of frail older adults: preliminary data from a pilot randomized controlled trial. J Am Geriatr Soc 2016:64:2144-8.

115 Tanner JA, Black BS, Johnston D, et al. A randomized controlled trial of a community-based dementia care coordination intervention: effects of mind at home on caregiver outcomes. Am J Geriatr Psychiatry 2015;23:391-402.

116 Radwany SM, Hazelett SE, Allen KR, et al. Results of the promoting effective advance care planning for elders (PEACE) randomized pilot study. Popul Health Manag 2014;17:106-11.

117 Montgomery RJV, Kwak J, Kosloski K. Effects of the TCARE $®$ intervention on caregiver burden and depressive symptoms: preliminary findings from a randomized controlled study. $J$ Gerontol B Psychol Sci Soc Sci 2011;66:640.

118 Lam LCW, Lee JSW, Chung JCC, et al. A randomized controlled trial to examine the effectiveness of case management model for community dwelling older persons with mild dementia in Hong Kong. Int J Geriatr Psychiatry 2010;25:395-402.

119 Kwok T, Lam L, Chung J. Case management to improve quality of life of older people with early dementia and to reduce caregiver burden. Hong Kong Med J 2012;18(Suppl 6):4-6.

120 Tuntland H, Aaslund MK, Espehaug B, et al. Reablement in community-dwelling older adults: a randomised controlled trial. BMC Geriatr 2015;15:145.

121 Black CR, Tidwell DK, Worthy SL. A randomized clinical trial comparing liberalized diets and therapeutic diets in long-term-care residents. J Acad Nutr Diatetics 2011;9.

122 Kwok TCY, Lam LCW, Sea MMM, et al. A randomized controlled trial of dietetic interventions to prevent cognitive decline in old age hostel residents. Eur J Clin Nutr 2012;66:1135-40.

123 Steven A, Wilson G, Young-Murphy L. The implementation of an innovative hydration monitoring APP in care home settings: a qualitative study. JMIR Mhealth Uhealth 2019;7:e9892-17.

124 Simmons SF, Keeler E, An R, et al. Cost-effectiveness of nutrition intervention in long-term care. J Am Geriatr Soc 2015;63:2308-16.
125 Stange I, Bartram M, Liao Y, et al. Effects of a low-volume, nutrientand energy-dense oral nutritional supplement on nutritional and functional status: a randomized, controlled trial in nursing home residents. J Am Med Dir Assoc 2013;14:628.e1.

126 Carlsson M, Littbrand H, Gustafson Y, et al. Effects of highintensity exercise and protein supplement on muscle mass in ADL dependent older people with and without malnutrition: a randomized controlled trial. J Nutr Health Aging 2011;15:554-60.

127 Simmons SF, Zhuo X, Keeler E. Cost-effectiveness of nutrition interventions in nursing home residents: a pilot intervention. J Nutr Health Aging 2010;14:367-72.

128 Krikorian R, Shidler MD, Nash TA, et al. Blueberry supplementation improves memory in older adults. J Agric Food Chem 2010;58:3996-4000.

129 Pouyet V, Giboreau A, Benattar L, et al. Attractiveness and consumption of finger foods in elderly Alzheimer's disease patients. Food Qual Prefer 2014;34:62-9.

130 Lin L-C, Huang Y-J, Watson R, et al. Using a Montessori method to increase eating ability for institutionalised residents with dementia: a crossover design. J Clin Nurs 2011;20:3092-101.

131 Zanini M, Bagnasco A, Catania G, et al. A dedicated nutritional care program (NUTRICARE) to reduce malnutrition in institutionalised dysphagic older people: a quasi-experimental study. J Clin Nurs 2017;26:4446-55.

132 Beck AM, Damkjaer K, Sørbye LW. Physical and social functional abilities seem to be maintained by a multifaceted randomized controlled nutritional intervention among old ( $>65$ years) Danish nursing home residents. Arch Gerontol Geriatr 2010;50:351-5.

133 Charras K, Frémontier M. Sharing meals with institutionalized people with dementia: a natural experiment. J Gerontol Soc Work 2010:53:436-48.

134 Kenkmann A, Hooper L, Lee H. The restaurant within the home: experiences of a restaurant-style dining provision in residential homes for older people. Qual Ageing Older Adults 2012;13:98-110.

135 Schilp J, Kruizenga HM, Wijnhoven HAH, et al. Effects of a dietetic treatment in older, undernourished, community-dwelling individuals in primary care: a randomized controlled trial. Eur $J$ Nutr 2013;52:1939-48.

136 Marchini L, Recker E, Hartshorn J, et al. lowa nursing facility oral hygiene (INFOH) intervention: a clinical and microbiological pilot randomized trial. Spec Care Dentist 2018:38:345-55.

137 Juthani-Mehta M, Van Ness PH, McGloin J, et al. A clusterrandomized controlled trial of a multicomponent intervention protocol for pneumonia prevention among nursing home elders. Clin Infect Dis 2015;60:849-57.

138 De Visschere L, Schols J, van der Putten G-J, et al. Effect evaluation of a supervised versus non-supervised implementation of an oral health care guideline in nursing homes: a cluster randomised controlled clinical trial. Gerodontology 2012;29:e96-106.

139 Lewis A, Wallace J, Deutsch A, et al. Improving the oral health of frail and functionally dependent elderly. Aust Dent J 2015;60(Suppl 1):95-105.

140 Sumi $\mathrm{Y}$, Ozawa N, Miura H, et al. Oral care help to maintain nutritional status in frail older people. Arch Gerontol Geriatr 2010;51:125-8.

141 Tomata Y, Watanabe T, Sugiyama K, et al. Effects of a communitybased program for oral health and nutrition on cost-effectiveness by preventing disability in Japanese frail elderly: a quasi-experimental study using propensity score matching. J Am Med Dir Assoc 2017;18:678-85.

142 Brienza D, Kelsey S, Karg P, et al. A randomized clinical trial on preventing pressure ulcers with wheelchair seat cushions. J Am Geriatr Soc 2010;58:2308-14.

143 Hahnel E, Blume-Peytavi U, Trojahn C, et al. The effectiveness of standardized skin care regimens on skin dryness in nursing home residents: a randomized controlled parallel-group pragmatic trial. Int $J$ Nurs Stud 2017;70:1-10.

144 Sánchez MCV, Prieto LMG, Del-Oro-Sáez CP, et al. Functional vision screening of older adults in nursing homes: a study from Galicia (northwest Spain). J Vis Impair Blind 2018;112:183-96.

145 Cohen-Mansfield J, Dakheel-Ali M, Jensen B, et al. An analysis of the relationships among engagement, agitated behavior, and affect in nursing home residents with dementia. Int Psychogeriatr 2012;24:742-52.

146 Janata P. Effects of widespread and frequent personalized music programming on agitation and depression in assisted living facility residents with Alzheimer-type dementia. Music Med 2012;4:8-15.

147 Aslakson M. The effects of a music therapy intervention on agitation in people with dementia. Milwaukee: University of Wisconsin, 2010.

148 Azcurra DJLS. A reminiscence program intervention to improve the quality of life of long-term care residents with Alzheimer's Disease. 
A randomized Controlled Trial. Revista Brasileira de Psiquiatria 2012;34:422-33.

149 Wenborn J, Challis D, Head J, et al. Providing activity for people with dementia in care homes: a cluster randomised controlled trial. Int J Geriatr Psychiatry 2013;28:1296-304.

150 Buettner LL, Fitzsimmons S, Dudley WN. Impact of underlying depression on treatment of neuropsychiatric symptoms in older adults with dementia. Res Gerontol Nurs 2010;3:221-32.

151 van der Ploeg ES, Eppingstall B, Camp CJ, et al. A randomized crossover trial to study the effect of personalized, one-to-one interaction using Montessori-based activities on agitation, affect, and engagement in nursing home residents with dementia. Int Psychogeriatr 2013;25:565-75.

152 Van Haitsma KS, Curyto K, Abbott KM, et al. A randomized controlled trial for an individualized positive psychosocial intervention for the affective and behavioral symptoms of dementia in nursing home residents. J Gerontol B Psychol Sci Soc Sci 2015;70:35-45.

153 Cho HK. The effects of music therapy-singing group on quality of life and affect of persons with dementia: a randomized controlled trial. Front Med 2018;5:1-13.

154 van Haeften-van Dijk AM, Meiland FJM, Hattink BJJ, et al. Community day care with carer support versus usual nursing homebased day care: effects on needs, behavior, mood, and quality of life of people with dementia. Int Psychogeriatr 2016;28:631-45.

155 Morgan SWB. Life review with people with dementia in care homes: a preliminary randomized controlled trial. Nonpharmacol Ther Dement 2012.

156 Haslam C, Haslam SA, Jetten J, et al. The social treatment: the benefits of group interventions in residential care settings. Psychol Aging 2010;25:157-67.

157 Galik E, Resnick B, Hammersla M, et al. Optimizing function and physical activity among nursing home residents with dementia: testing the impact of function-focused care. Gerontologist 2014:54:930-43.

158 Kolanowski A, Litaker M, Buettner L, et al. A randomized clinical trial of theory-based activities for the behavioral symptoms of dementia in nursing home residents. J Am Geriatr Soc 2011;59:1032-41.

159 Cohen-Mansfield J, Thein K, Marx MS, et al. Efficacy of nonpharmacologic interventions for agitation in advanced dementia: a randomized, placebo-controlled trial. J Clin Psychiatry 2012;73:1255-61.

160 Fu C-Y, Moyle W, Cooke M. A randomised controlled trial of the use of aromatherapy and hand massage to reduce disruptive behaviour in people with dementia. BMC Complement Altern Med 2013;13:165

161 Moyle W, Cooke ML, Beattie E, et al. Foot massage versus quiet presence on agitation and mood in people with dementia: a randomised controlled trial. Int J Nurs Stud 2014:51:856-64.

162 Gitlin LN, Winter L, Dennis MP, et al. A biobehavioral home-based intervention and the well-being of patients with dementia and their caregivers: the cope randomized trial. JAMA 2010;304:98.

163 dos Santos Mendes FA, Pompeu JE, Modenesi Lobo A, et al. Motor learning, retention and transfer after virtual-reality-based training in Parkinson's disease--effect of motor and cognitive demands of games: a longitudinal, controlled clinical study. Physiotherapy 2012:98:217-23.

164 Sung H-C, Chang AM, Lee W-L. A preferred music listening intervention to reduce anxiety in older adults with dementia in nursing homes. J Clin Nurs 2010;19:1056-64.

165 Davison TE, Eppingstall B, Runci S, et al. A pilot trial of acceptance and commitment therapy for symptoms of depression and anxiety in older adults residing in long-term care facilities. Aging Ment Health 2017;21:766-73.

166 Dozeman E, van Marwijk HWJ, van Schaik DJF, et al. Contradictory effects for prevention of depression and anxiety in residents in homes for the elderly: a pragmatic randomized controlled trial. Int Psychogeriatr 2012;24:1242-51.

167 Chuang H-W, Kao C-W, Lee M-D, et al. Effectiveness of StoryCentred care intervention program in older persons living in longterm care facilities: a randomized, longitudinal study. PLoS One 2018;13:e0194178.

168 Moretti F, De Ronchi D, Bernabei V, et al. Pet therapy in elderly patients with mental illness. Psychogeriatrics 2011;11:125-9.

169 Lohman MC, Raue PJ, Greenberg RL, et al. Reducing suicidal ideation in home health care: results from the CAREPATH depression care management trial. Int J Geriatr Psychiatry 2016:31:708-15.

$170 \mathrm{Kim}$ J-P, Yang J. Effectiveness of a community-based program for suicide prevention among elders with early-stage dementia: a controlled observational study. Geriatr Nurs 2017;38:97-105.
171 Figueiro MG, Plitnick B, Roohan C, et al. Effects of a tailored lighting intervention on sleep quality, rest-activity, mood, and behavior in older adults with Alzheimer disease and related dementias: a randomized clinical trial. J Clin Sleep Med 2019;15:1757-67.

172 Royer M, Ballentine NH, Eslinger PJ, et al. Light therapy for seniors in long term care. J Am Med Dir Assoc 2012;13:100-2.

173 Wu M-C, Sung H-C, Lee W-L, et al. The effects of light therapy on depression and sleep disruption in older adults in a long-term care facility. Int J Nurs Pract 2015;21:653-9.

174 McCurry SM, Pike KC, Vitiello MV, et al. Increasing walking and bright light exposure to improve sleep in community-dwelling persons with Alzheimer's disease: results of a randomized, controlled trial. J Am Geriatr Soc 2011;59:1393-402.

175 Boström G, Conradsson M, Hörnsten C, et al. Effects of a highintensity functional exercise program on depressive symptoms among people with dementia in residential care: a randomized controlled trial. Int J Geriatr Psychiatry 2016;31:868-78.

176 Stolee P, Zaza C, Schuehlein S. Evaluation of a volunteer-led in-home exercise program for home-bound older adults. Work 2012:41:339-54.

177 Schreier MM, Bauer U, Osterbrink J, et al. Fitness training for the old and frail. effectiveness and impact on daily life coping and selfcare abilities. Z Gerontol Geriatr 2016:49:107-14

178 Lustosa L, Silva J, Coelho F. Impact of resistance exercise program on functional capacity and muscular strength of knee extensor in pre-frail community-dwelling older women: a randomized crossover trial (Efeito de Um programa de resistência muscular $\mathrm{Na}$ capacidade funcional E Na força. Rev Bras Fisioter 2011:15.

179 Kanda K, Mori Y, Yamasaki K, et al. Long-term effects of lowintensity training with slow movement on motor function of elderly patients: a prospective observational study. Environ Health Prev Med 2019;24:1-8.

180 Barthalos I, Dorgo S, Kopkáné Plachy J, et al. Randomized controlled resistance training based physical activity trial for central European nursing home residing older adults. J Sports Med Phys Fitness 2016;56:1249-57.

181 Zech A, Drey M, Freiberger E, et al. Residual effects of muscle strength and muscle power training and detraining on physical function in community-dwelling prefrail older adults: a randomized controlled trial. BMC Geriatr 2012;12:68.

182 Henwood T, Hetherington S, Purss M, et al. Active@home: Investigating the value of a home care worker-led exercise program for older adults with complex care needs. J Aging Phys Act 2019;27:284-9.

183 Langlois F, Vu TTM, Chassé K, et al. Benefits of physical exercise training on cognition and quality of life in frail older adults. $J$ Gerontol B Psychol Sci Soc Sci 2013;68:400-4.

184 Ohtake M, Morikagi Y, Suzuki I, et al. Effects of exercise on the prevention of conditions leading to the need for long-term care. Aging Clin Exp Res 2013;25:49-57.

185 Wu Y-Z, Lin J-Y, Wu P-L, et al. Effects of a hybrid intervention combining exergaming and physical therapy among older adults in a long-term care facility. Geriatr Gerontol Int 2019;19:147-52.

186 Makizako H, Shimada H, Doi T, et al. Effects of a community disability prevention program for frail older adults at 48-month follow up. Geriatr Gerontol Int 2017;17:2347-53.

187 Foley AL, Hillier S, Barnard R. Effectiveness of once-weekly gymbased exercise programmes for older adults post discharge from day rehabilitation: a randomised controlled trial. $\mathrm{Br} J$ Sports Med 2011:45:978-86.

188 Cesari M, Vellas B, Hsu F-C, et al. A physical activity intervention to treat the frailty syndrome in older persons-results from the LIFE-P study. J Gerontol A Biol Sci Med Sci 2015;70:216-22.

189 Freiberger E, Häberle L, Spirduso WW, et al. Long-term effects of three multicomponent exercise interventions on physical performance and fall-related psychological outcomes in community-dwelling older adults: a randomized controlled trial. $J$ Am Geriatr Soc 2012;60:437-46.

190 Clemson L, Fiatarone Singh MA, Bundy A, et al. Integration of balance and strength training into daily life activity to reduce rate of falls in older people (the life study): randomised parallel trial. BMJ 2012;345:1-15.

191 Grönstedt H, Frändin K, Bergland A, et al. Effects of individually tailored physical and daily activities in nursing home residents on activities of daily living, physical performance and physical activity level: a randomized controlled trial. Gerontology 2013;59:220-9.

192 Villareal DT, Chode S, Parimi N, et al. Weight loss, exercise, or both and physical function in obese older adults. Obstet Gynecol Surv 2011;66:488-9.

193 Pollock RD, Martin FC, Newham DJ. Whole-body vibration in addition to strength and balance exercise for falls-related functional 
mobility of frail older adults: a single-blind randomized controlled trial. Clin Rehabil 2012;26:915-23.

194 Tousignant M, Corriveau H, Roy P-M, et al. Efficacy of supervised Tai chi exercises versus conventional physical therapy exercises in fall prevention for frail older adults: a randomized controlled trial. Disabil Rehabil 2013;35:1429-35.

195 Miller KL, Magel JR, Hayes JG. The effects of a home-based exercise program on balance confidence, balance performance, and gait in debilitated, ambulatory community-dwelling older adults: a pilot study. J Geriatr Phys Ther 2010;33:85-91.

196 Danilovich MK, Conroy DE, Hornby TG. Feasibility and impact of high-intensity walking training in frail older adults. J Aging Phys Act 2017;25:533-8.

197 Giné-Garriga M, Guerra M, Pagès E, et al. The effect of functional circuit training on physical frailty in frail older adults: a randomized controlled trial. J Aging Phys Act 2010;18:401-24.

198 Edgren J, Salpakoski A, Sihvonen SE, et al. Effects of a homebased physical rehabilitation program on physical disability afte hip fracture: a randomized controlled trial. J Am Med Dir Assoc 2015;16:350.e1-7.

199 Kamegaya T, Maki Y, et al, Long-Term-Care Prevention Team of Maebashi City. Pleasant physical exercise program for prevention of cognitive decline in community-dwelling elderly with subjective memory complaints. Geriatr Gerontol Int 2012;12:673-9.

200 Clegg A, Barber S, Young J, et al. The home-based older people's exercise (HOPE) trial: a pilot randomised controlled trial of a homebased exercise intervention for older people with frailty. Age Ageing 2014;43:687-95.

201 Venturelli M, Lanza M, Muti E, et al. Positive effects of physical training in activity of daily living-dependent older adults. Exp Aging Res 2010;36:190-205.

202 Sievänen H, Karinkanta S, Moisio-Vilenius P, et al. Feasibility of whole-body vibration training in nursing home residents with low physical function: a pilot study. Aging Clin Exp Res 2014;26:511-7.

203 Cadore EL, Casas-Herrero A, Zambom-Ferraresi F, et al. Multicomponent exercises including muscle power training enhance muscle mass, power output, and functional outcomes in institutionalized frail nonagenarians. Age 2014;36:773-85.

204 Bösner S, Keller H, Wöhner A, et al. Prevention of falls by outdoorwalking in elderly persons at risk ("power") - a pilot study. Eur Geriatr Med 2012;3:28-32

205 Brustio PR, Magistro D, Ivaldi S, et al. Neuromotor training in older women living in long-term care setting: a pilot study. Geriatr Nurs 2015;36:361-6.

206 Kovács E, Sztruhár Jónásné I, Karóczi CK, et al. Effects of a multimodal exercise program on balance, functional mobility and fall risk in older adults with cognitive impairment: a randomized controlled single-blind study. Eur J Phys Rehabil Med 2013;49:639-48.

207 Comans TA, Brauer SG, Haines TP. Randomized trial of domiciliary versus center-based rehabilitation: which is more effective in reducing falls and improving quality of life in older fallers? $J$ Gerontol A Biol Sci Med Sci 2010;65:672-9.

208 Krampe J, Rantz MJ, Dowell L, et al. Dance-based therapy in a program of all-inclusive care for the elderly: an integrative approach to decrease fall risk. Nurs Adm Q 2010;34:156.

209 da Silva Borges EG, de Souza Vale RG, Cader SA, et al. Postural balance and falls in elderly nursing home residents enrolled in a ballroom dancing program. Arch Gerontol Geriatr 2014;59:312-6.

210 Jeon MY, Jeong H, Petrofsky J, et al. Effects of a randomized controlled recurrent fall prevention program on risk factors for falls in frail elderly living at home in rural communities. Med Sci Monit 2014;20:2283-91.

211 Ožić S, Vasiljev V, Ivković V, et al. Interventions aimed at loneliness and fall prevention reduce frailty in elderly urban population. Medicine 2020;99:e19145.

212 Broadbent S, Crowley-McHattan Z, Zhou S, et al. The effect of the Nintendo Wii fit on exercise capacity and gait in an elderly woman with CREST syndrome. Int J Ther Rehabil 2014

213 Bainbridge E, Bevans S, Keeley B, et al. The effects of the Nintendo Wii fit on community-dwelling older adults with perceived balance deficits: a pilot study. Phys Occup Ther Geriatr 2011;29:126-35.

214 Esculier J-F, Vaudrin J, Bériault P, et al. Home-based balance training programme using Wii fit with balance board for Parkinsons's disease: a pilot study. J Rehabil Med 2012;44:144-50.

215 Mhatre PV, Vilares I, Stibb SM, et al. Wii fit balance board playing improves balance and gait in Parkinson disease. $P m R$ 2013;5:769-77.

216 Pompeu JE, Mendes FADS, Silva KGda, et al. Effect of Nintendo $\mathrm{Wii}^{\mathrm{TM}}$-based motor and cognitive training on activities of daily living in patients with Parkinson's disease: a randomised clinical trial. Physiotherapy 2012;98:196-204.

217 Mugueta-Aguinaga I, Garcia-Zapirain B. Frailty level monitoring and analysis after a pilot six-week randomized controlled clinical trial using the FRED exergame including biofeedback supervision in an elderly day care centre. Int J Environ Res Public Health 2019;16:729-22.

218 Hakim RM, Salvo CJ, Balent A, et al. Case report: a balance training program using the Nintendo Wii fit to reduce fall risk in an older adult with bilateral peripheral neuropathy. Physiother Theory Pract 2015;31:130-9.

219 Daniel K. Wii-hab for pre-frail older adults. Rehabil Nurs 2012;37:195-201.

220 Agmon M, Perry CK, Phelan E, et al. A pilot study of Wii fit exergames to improve balance in older adults. J Geriatr Phys Ther 2011;34:161-7

221 van den Berg M, Sherrington C, Killington M, et al. Video and computer-based interactive exercises are safe and improve task-specific balance in geriatric and neurological rehabilitation: a randomised trial. J Physiother 2016;62:20-8.

222 Shih M-C, Wang R-Y, Cheng S-J, et al. Effects of a balance-based exergaming intervention using the Kinect sensor on posture stability in individuals with Parkinson's disease: a single-blinded randomized controlled trial. J Neuroeng Rehabil 2016;13:1-9.

223 Arlati S, Colombo V, Spoladore D, et al. A social virtual reality-based application for the physical and cognitive training of the elderly at home. Sensors 2019;19:1-17.

224 Fu AS, Gao KL, Tung AK, et al. Effectiveness of Exergaming training in reducing risk and incidence of falls in frail older adults with a history of falls. Arch Phys Med Rehabil 2015;96:2096-102.

225 Chen K-M, Li C-H, Huang H-T, et al. Feasible modalities and longterm effects of elastic band exercises in nursing home older adults in wheelchairs: a cluster randomized controlled trial. Int J Nurs Stud 2016;55:4-14.

226 Watt JR, Jackson K, Franz JR, et al. Effect of a supervised hip flexor stretching program on gait in frail elderly patients. $P m R$ 2011;3:330-5.

227 Chen K-M, Chen M-H, Lin M-H, et al. Effects of yoga on sleep quality and depression in elders in assisted living facilities. $J$ Nurs Res 2010;18:53-61.

228 Sato D, Kaneda K, Wakabayashi $\mathrm{H}$, et al. Comparison of once and twice Weekly water exercise on various bodily functions in community-dwelling frail elderly requiring nursing care. Arch Gerontol Geriatr 2011:52:331-5

229 Yamada M, Arai H, Sonoda T, et al. Community-based exercise program is cost-effective by preventing care and disability in Japanese frail older adults. J Am Med Dir Assoc 2012;13:507-11.

230 Tarazona-Santabalbina FJ, Gómez-Cabrera MC, Pérez-Ros P, et al. A multicomponent exercise intervention that reverses frailty and improves cognition, emotion, and social networking in the community-dwelling frail elderly: a randomized clinical trial. J Am Med Dir Assoc 2016;17:426-33.

231 Roach KE, Tappen RM, Kirk-Sanchez N, et al. A randomized controlled trial of an activity specific exercise program for individuals with Alzheimer disease in long-term care settings. J Geriatr Phys Ther 2011;34:50-6.

232 Edgren J, Rantanen T, Heinonen A, et al. Effects of progressive resistance training on physical disability among older communitydwelling people with history of hip fracture. Aging Clin Exp Res 2013:24:171-5

233 Rodríguez-Díaz MT, Pérez-Marfil MN, Cruz-Quintana F. Coexisting with dependence and well-being: the results of a pilot study intervention on 75-99-year-old individuals. Int Psychogeriatr 2016;28:2067-78.

234 Serra-Rexach JA, Bustamante-Ara N, Hierro Villarán M, et al. Shortterm, light- to moderate-intensity exercise training improves leg muscle strength in the oldest old: a randomized controlled trial. $J$ Am Geriatr Soc 2011;59:594-602.

235 Underwood M, Lamb SE, Eldridge S, et al. Exercise for depression in elderly residents of care homes: a cluster-randomised controlled trial. Lancet 2013;382:41-9.

236 Liu JY-W, Lai CK, Siu PM, et al. An individualized exercise programme with and without behavioural change enhancement strategies for managing fatigue among frail older people: a quasiexperimental pilot study. Clin Rehabil 2017;31:1-11.

237 Hagedorn DK, Holm E. Effects of traditional physical training and visual computer feedback training in frail elderly patients. A randomized intervention study. Eur J Phys Rehabil Med 2010;46:159-68.

238 Hsu C-Y, Moyle W, Cooke M, et al. Seated T'ai chi in older Taiwanese people using wheelchairs: a randomized controlled trial 
investigating mood states and self-efficacy. J Altern Complement Med 2016;22:990-6.

239 Nomura T, Nagano K, Takato J, et al. The development of a tai chi exercise regimen for the prevention of conditions requiring longterm care in Japan. Arch Gerontol Geriatr 2011;52:e198-203.

240 Taylor D, Hale L, Schluter P, et al. Effectiveness of tai chi as a community-based falls prevention intervention: a randomized controlled trial. J Am Geriatr Soc 2012;60:841-8.

241 Yao L, Foley KT, Kolanowski AM, et al. Proto tai chi: in search of a promising group exercise for the frail elderly. Geriatr Nurs 2014;35:S21-6.

242 Buckinx F, Beaudart C, Maquet D, et al. Evaluation of the impact of 6 -month training by whole body vibration on the risk of falls among nursing home residents, observed over a 12-month period: a single blind, randomized controlled trial. Aging Clin Exp Res 2014;26:369-76.

243 Ito S, Hashimoto M, Aduma S, et al. Effectiveness of locomotion training in a home visit preventive care project: one-group preintervention versus post-intervention design study. J Orthop Sci 2015;20:1078-84

244 Slaughter SE, Wagg AS, Jones CA, et al. Mobility of vulnerable elders study: effect of the sit-to-stand activity on mobility, function, and quality of life. J Am Med Dir Assoc 2015;16:138-43.

245 Muramatsu N, Yin L, Berbaum ML, et al. Promoting seniors' health with home care Aides: a pilot. Gerontologist 2018;58:779-88.

246 Huang T-T, Yang S-D, Tsai Y-H, et al. Effectiveness of individualised intervention on older residents with constipation in nursing home: a randomised controlled trial. J Clin Nurs 2015;24:3449-58.

247 van den Nieuwboer M, Klomp-Hogeterp A, Verdoorn S, et al. Improving the bowel habits of elderly residents in a nursing home using probiotic fermented milk. Benef Microbes 2015;6:397-403.

248 Talley KMC, Wyman JF, Bronas U, et al. Defeating urinary incontinence with exercise training: results of a pilot study in frail older women. J Am Geriatr Soc 2017;65:1321-7.

249 Gené Huguet L, Navarro González M, Kostov B, et al. Pre frail 80: multifactorial intervention to prevent progression of Pre-Frailty to frailty in the elderly. J Nutr Health Aging 2018;22:1266-74.

250 Lewin G, De San Miguel K, Knuiman M, et al. A randomised controlled trial of the home independence program, an Australian restorative home-care programme for older adults. Health Soc Care Community 2013;21:69-78.

251 Serra-Prat M, Sist X, Domenich R, et al. Effectiveness of an intervention to prevent frailty in pre-frail community-dwelling older people consulting in primary care: a randomised controlled trial. Age Ageing 2017;46:3.

252 Kimura M, Moriyasu A, Kumagai S, et al. Community-based intervention to improve dietary habits and promote physical activity among older adults: a cluster randomized trial. BMC Geriatr 2013;13:8

253 Rydwik E, Frändin K, Akner G. Effects of a physical training and nutritional intervention program in frail elderly people regarding habitual physical activity level and activities of daily living- a randomized controlled pilot study. Arch Gerontol Geriatr 2010;51:283-9.

254 Abizanda P, López MD, García VP, et al. Effects of an oral nutritional supplementation plus physical exercise intervention on the physical function, nutritional status, and quality of life in frail institutionalized older adults: the ACTIVNES study. J Am Med Dir Assoc 2015;16:439.e9-16.

255 Haider S, Dorner TE, Luger E, et al. Impact of a home-based physical and nutritional intervention program conducted by layvolunteers on handgrip strength in prefrail and frail older adults: a randomized control trial. PLOS One 2017;12:1-15.

256 Winzer E, Dorner TE, Grabovac I, et al. Behavior changes by a buddy-style intervention including physical training, and nutritional and social support. Geriatr Gerontol Int 2019;19:323-9.

257 Kwon J, Yoshida Y, Yoshida H, et al. Effects of a combined physical training and nutrition intervention on physical performance and health-related quality of life in prefrail older women living in the community: a randomized controlled trial. J Am Med Dir Assoc 2015;16:263.e1-8.

258 Lu Y, Niti M, Yap KB, et al. Assessment of sarcopenia among community-dwelling at-risk frail adults aged 65 years and olde who received multidomain lifestyle interventions: a secondary analysis of a randomized clinical trial. JAMA Netw Open 2019;2:e1913346.

259 Ng TP, Feng L, Nyunt MSZ, et al. Nutritional, physical, cognitive, and combination interventions and frailty reversal among older adults: a randomized controlled trial. Am J Med 2015;128:1225-36.

260 Yuri Y, Takabatake S, Nishikawa T, et al. The effects of a life goalsetting technique in a preventive care program for frail community- dwelling older people: a cluster nonrandomized controlled trial. BMC Geriatr 2016;16:1-11.

261 Apóstolo J, Dixe MDA, Bobrowicz-Campos E, et al. Effectiveness of a combined intervention on psychological and physical capacities of frail older adults: a cluster randomized controlled trial. Int $J$ Environ Res Public Health 2019;16:1-18.

262 Jang I-Y, Jung $\mathrm{H}-\mathrm{W}$, Park $\mathrm{H}$, et al. A multicomponent frailty intervention for socioeconomically vulnerable older adults: a designed-delay study. Clin Interv Aging 2018;13:1799-814.

263 Ruikes FGH, Zuidema SU, Akkermans RP, et al. Multicomponent program to reduce functional decline in frail elderly people: a cluster controlled trial. J Am Board Fam Med 2016;29:209.

264 Clark F, Jackson J, Carlson M, et al. Effectiveness of a lifestyle intervention in promoting the well-being of independently living older people: results of the well elderly 2 randomised controlled trial. J Epidemiol Community Health 2012;66:782-90.

265 Rantanen T, Äyräväinen I, Eronen J, et al. The effect of an outdoor activities' intervention delivered by older volunteers on the quality of life of older people with severe mobility limitations: a randomized controlled trial. Aging Clin Exp Res 2015;27:161-9.

266 Duyan V, Şahin-Kara G, Camur Duyan G, et al. The effects of group work with institutionalized elderly persons. Res Soc Work Pract 2017:27:366-74.

267 Imai H, Furukawa TA, Okumiya K, et al. Postcard intervention for depression in community-dwelling older adults: a randomised controlled trial. Psychiatry Res 2015;229:545-50.

268 Chochinov HM, Cann B, Cullihall K, et al. Dignity therapy: a feasibility study of elders in long-term care. Palliat Support Care 2012;10:3-15.

269 Tsai H-H, Tsai Y-F. Changes in depressive symptoms, social support, and loneliness over 1 year after a minimum 3-month videoconference program for older nursing home residents. $J$ Med Internet Res 2011:13:e93.

270 Moyle W, Jones CJ, Murfield JE, et al. Use of a robotic seal as a therapeutic tool to improve dementia symptoms: a clusterrandomized controlled trial. J Am Med Dir Assoc 2017;18:766-73.

271 Behm L, Eklund K, Wilhelmson K, et al. Health promotion can Postpone frailty: results from the RCT elderly persons in the risk zone. Public Health Nurs 2016;33:303-15.

272 Gustafsson S, Berglund H, Faronbi J, et al. Minor positive effects of health-promoting senior meetings for older community-dwelling persons on loneliness, social network, and social support. Clin Interv Aging 2017;12:1867-1.

273 Spoorenberg SLW, Wynia K, Uittenbroek RJ, et al. Effects of a population-based, person-centred and integrated care service on health, wellbeing and self-management of community-living older adults: a randomised controlled trial on embrace. PLoS One 2018;13:1-16.

274 Barrios MD, Pardo L, Ceballo G. Fragilidad em el adulto mayor: intervención educativa sobre Los cuidados em El anciano. MEDICIEGO 2010;16.

275 Yao Y-F, Chen K-M. Effects of horticulture therapy on nursing home older adults in southern Taiwan. Qual Life Res 2017;26:1007-14.

276 Masuya J, Ota K, Mashida Y. The effect of a horticultural activities program for the community elderly. Int J Nurs Clin Pract 2017;4.

277 Mitoku K, Shimanouchi S. Home modification and prevention of frailty progression in older adults: a Japanese prospective cohort study. J Gerontol Nurs 2014;40:40-7.

278 Whitehead PJ, Golding-Day MR, Belshaw S, et al. Bathing adaptations in the homes of older adults (BATH-OUT): results of a feasibility randomised controlled trial (RCT). BMC Public Health 2018:18:1-11.

279 Gustavsson J, Bonander C, Andersson R, et al. Investigating the fall-injury reducing effect of impact absorbing flooring among female nursing home residents: initial results. Inj Prev 2015;21:320-4.

280 de Almeida Mello J, Declercq A, Cès S, et al. Exploring home care interventions for frail older people in Belgium: a comparative effectiveness study. J Am Geriatr Soc 2016;64:2251-6.

281 Borrows A, Holland R. Independent living centre occupational therapy (OT) versus routine community OT. Int $J$ Ther Rehabil 2014;20.

282 Arentshorst ME, Kloet RR, Peine A. Intergenerational housing: the case of Humanitas Netherlands. J Hous Elderly 2019;33:244-56.

283 Gitlin LN. Enhancing quality of life in functionally vulnerable older adults: from randomized trial to standard care: individuals at any age can learn new strategies to engage in valued activities. Generations 2010;34:84-8.

284 Möller UO, Kristensson J, Midlöv P, et al. Effects of a one-year home-based case management intervention on falls in older people: a randomized controlled trial. J Aging Phys Act 2014;22:457-64. 
285 Fahlström G, Kamwendo K, Forsberg J, et al. Fall prevention by nursing assistants among community-living elderly people. A randomised controlled trial. Scand J Caring Sci 2018;32:575-85.

286 Vind AB, Andersen HE, Pedersen KD, et al. Effect of a program of multifactorial fall prevention on health-related quality of life, functional ability, fear of falling and psychological well-being. A randomized controlled trial. Aging Clin Exp Res 2010;22:249-54.

287 Otaka Y, Morita M, Mimura T, et al. Establishment of an appropriate fall prevention program: a community-based study. Geriatr Gerontol Int 2017:17:1081-9.

288 Casteel C, Bruening R, Carson M, et al. Evaluation of a falls and fire safety program for community-dwelling older adults. J Community Health 2020;45:717-27.

289 Markle-Reid M, Browne G, Gafni A. Nurse-led health promotion interventions improve quality of life in frail older home care clients: lessons learned from three randomized trials in Ontario, Canada. $J$ Eval Clin Pract 2013;19:118-31.

290 Dorresteijn TAC, Zijlstra GAR, Ambergen AW, et al. Effectiveness of a home-based cognitive behavioral program to manage concerns about falls in community-dwelling, frail older people: results of a randomized controlled trial. BMC Geriatr 2016;16:2.

291 Faes MC, Reelick MF, Melis RJ, et al. Multifactorial fall prevention for pairs of frail community-dwelling older fallers and their informal caregivers: a dead end for complex interventions in the frailest fallers. J Am Med Dir Assoc 2011;12:451-8.

292 Huang T-T, Chung M-L, Chen F-R, et al. Evaluation of a combined cognitive-behavioural and exercise intervention to manage fear of falling among elderly residents in nursing homes. Aging Ment Health 2016;20:2-12.

293 Tchalla AE, Lachal F, Cardinaud N, et al. Preventing and managing indoor falls with home-based technologies in mild and moderate Alzheimer's disease patients: pilot study in a community dwelling. Dement Geriatr Cogn Disord 2013;36:251-61.

294 Cino K. Aromatherapy hand massage for older adults with chronic pain living in long-term care. J Holist Nurs 2014;32:304-13; quiz 314-5.

295 Olsson IN, Curman B, Engfeldt P. Patient focused drug surveillance of elderly patients in nursing homes. Pharmacoepidemiol Drug Saf 2010;19:150-7.

296 Milos V, Rekman E, Bondesson Åsa, et al. Improving the quality of pharmacotherapy in elderly primary care patients through medication reviews: a randomised controlled study. Drugs Aging 2013;30:235-46.

297 Brulhart MI, Wermeille JP. Multidisciplinary medication review: evaluation of a pharmaceutical care model for nursing homes. Int $J$ Clin Pharm 2011;33:549-57.

298 Garfinkel D, Mangin D. Feasibility study of a systematic approach for discontinuation of multiple medications in older adults: addressing polypharmacy. Arch Intern Med 2010;170:1648-54.
299 Patterson SM, Hughes CM, Crealey G, et al. An evaluation of an adapted U.S. model of pharmaceutical care to improve psychoactive prescribing for nursing home residents in Northern Ireland (fleetwood Northern Ireland study). J Am Geriatr Soc 2010;58:44-53.

300 Lapane KL, Hughes CM, Daiello LA, et al. Effect of a pharmacist-led multicomponent intervention focusing on the medication monitoring phase to prevent potential adverse drug events in nursing homes. $J$ Am Geriatr Soc 2011;59:1238-45.

301 Halvorsen KH, Ruths S, Granas AG, et al. Multidisciplinary intervention to identify and resolve drug-related problems in Norwegian nursing homes. Scand J Prim Health Care 2010;28:82-8.

302 Ornstein K, Hernandez CR, DeCherrie LV, et al. The Mount Sinai (New York) visiting doctors program: meeting the needs of the urban homebound population. Care Manag Journals 2011;12:139-43.

303 Orlandoni P, Jukic Peladic N, Spazzafumo L, et al. Utility of video consultation to improve the outcomes of home enteral nutrition in a population of frail older patients. Geriatr Gerontol Int 2016;16:762-7.

304 Dham P, Gupta N, Alexander J, et al. Community based telepsychiatry service for older adults residing in a rural and remote region- utilization pattern and satisfaction among stakeholders. BMC Psychiatry 2018;18:1-13.

305 Dy P, Morin PC, Weinstock RS. Use of telemedicine to improve glycemic management in a skilled nursing facility: a pilot study. Telemed J E Heal 2013;19:643-5.

306 Queyroux A, Saricassapian B, Herzog D, et al. Accuracy of Teledentistry for diagnosing dental pathology using direct examination as a gold standard: results of the Tel-e-dent study of older adults living in nursing homes. J Am Med Dir Assoc 2017;18:528-32.

307 Upatising B, Hanson GJ, Kim YL, et al. Effects of home telemonitoring on transitions between frailty states and death for older adults: a randomized controlled trial. Int J Gen Med 2013;6:145-51.

308 Gellis ZD, Kenaley B, McGinty J, et al. Outcomes of a telehealth intervention for homebound older adults with heart or chronic respiratory failure: a randomized controlled trial. Gerontologist 2012:52:541-52.

309 Lewis C, Moore Z, Doyle F, et al. A community virtual ward model to support older persons with complex health care and social care needs. Clin Interv Aging 2017;12:985-93.

310 Makai P, Perry M, Robben SHM, et al. Evaluation of an eHealth intervention in chronic care for frail older people: why adherence is the first target. J Med Internet Res 2014;16:e156.

311 Poscia A, Collamati A, Carfi A, et al. Influenza and pneumococcal vaccination in older adults living in nursing home: a survival analysis on the shelter study. Eur J Public Health 2017;27:1016-20. 